\title{
Pelvic and hind limb musculature of Staurikosaurus pricei (Dinosauria: Saurischia)
}

\author{
ORLANDO N. GRILLO and SERGIO A.K. AZEVEDO \\ Departamento de Geologia e Paleontologia, Museu Nacional/UFRJ \\ Quinta da Boa Vista, s/n, São Cristóvão, 20940-040 Rio de Janeiro, RJ, Brasil \\ Manuscript received on January 15, 2010; accepted for publication on June 21, 2010
}

\begin{abstract}
The study of pelvic and hind limb bones and muscles in basal dinosaurs is important for understanding the early evolution of bipedal locomotion in the group. The use of data from both extant and extinct taxa placed into a phylogenetic context allowed to make well-supported inferences concerning most of the hind limb musculature of the basal saurischian Staurikosaurus pricei Colbert, 1970 (Santa Maria Formation, Late Triassic of Rio Grande do Sul, Brazil). Two large concavities in the lateral surface of the ilium represent the origin of the muscles iliotrochantericus caudalis plus iliofemoralis externus (in the anterior concavity) and iliofibularis (in the posterior concavity). Muscle ambiens has only one head and originates from the pubic tubercle. The origin of puboischiofemoralis internus 1 possibly corresponds to a fossa in the ventral margin of the preacetabular iliac process. This could represent an intermediate stage prior to the origin of a true preacetabular fossa. Muscles caudofemorales longus et brevis were likely well developed, and Staurikosaurus is unique in bearing a posteriorly projected surface for the origin of caudofemoralis brevis.
\end{abstract}

Key words: extant phylogenetic bracket, locomotion, muscular reconstruction, Saurischia, Staurikosaurus pricei.

\section{INTRODUCTION}

Bipedalism is a form of locomotion adopted by few groups of animals (Alexander 2004, Gatesy and Biewener 1991, Hutchinson and Gatesy 2006, McGowan 1999). Dinosaurs first evolved as bipedal animals and all living representatives of this clade are bipeds. The evolution of this type of locomotion is associated with several modifications in posture, orientation of the hind limbs, as well as correlated osteological and myological modifications. Understanding bipedal locomotion in dinosaurs requires multidisciplinary approach.

According to Lockley and Gillette (1989), studies of trackways dating from the $19^{\text {th }}$ century allowed the estimate of velocity (Alexander 1976, Farlow 1981, Day et al. 2002) and posture (Coombs 1980, Ishigaki 1989,

Proceedings of the Third Gondwanan Dinosaur Symposium Correspondence to: Orlando N. Grillo

E-mail: ongrillo@gmail.com
Thulborn 1989, Wade 1989, Jones et al. 2000, Day et al. 2002) of dinosaurs. Comparisons with living animals have often been used (e.g. Paul 1988, 1998, Carrano 1999, 2001, Jones et al. 2000, Hutchinson 2004a, b). New studies using advanced graphic computing and engineering principles (e.g., Gatesy et al. 1999, Stokstad 2001, Hutchinson and Garcia 2002, Wilhite 2003) and computed tomography (e.g., Carrier et al. 2001, Rayfield et al. 2001) also revealed important aspects of posture and locomotion, such as mass and center of mass position (e.g., Henderson 1999, Seebacher 2001). In addition, muscle reconstructions have led to new propositions about dinosaur locomotion (e.g., Hutchinson et al. 2005).

The first reconstruction of dinosaur pelvic musculature was made by Huene in 1908 (Romer 1923a), followed by some authors that studied saurischian musculature focusing on data obtained from living crocodiles 
(Romer 1923a, b, Colbert 1964, Coombs 1979). More recent works (e.g., Dilkes 2000, Hutchinson 2001a, b, 2002, Carrano and Hutchinson 2002, Langer 2003) made more extensive use of avian data, resulting in reconstructions that are consistent with the phylogenetic positions of the studied taxa.

Witmer $(1995,1997)$ proposed a methodology (Extant Phylogenetic Bracket, EPB) based on phylogenetic relationships and parsimony that allows the reconstruction of soft tissue features in extinct animals using an accurate approach (see also Bryant and Russell 1992 for an independently-devised but similar approach). EPB is suitable for muscle reconstructions, requiring a minimal level of speculation, and can be improved if associated with data from extinct species with close phylogenetic affinities. This association can reveal important osteological transformations that sometimes are not clear when the study relies only on data from extant species (Hutchinson 2001a). Several works on dinosaur limb muscle reconstruction have used the EPB (Dilkes 2000, Gatesy 1990, Hutchinson and Gatesy 2000, Hutchinson 2001a, b, 2002, Carrano and Hutchinson 2002, Langer 2003, Jasinoski et al. 2006). Most of these studies focused mainly on questions related to the origin and evolution of avian locomotion (Gatesy 1999, Hutchinson 2001a, b, 2002). Some authors presented simplified propositions for musculature and locomotion in basal dinosaurs (Carrano 2000, Hutchinson and Gatesy 2000, Hutchinson 2001a, b, 2002), but no detail on the locomotion in the earliest dinosaurs was provided.

The evolutionary success of Dinosauria, including birds, has often been attributed to their bipedal and erect posture that freed their hands from a locomotor function, allowing their use for capturing and manipulating prey (Paul 1988) and later for flight. Accordingly, the study of the locomotion on the early evolution of Dinosauria is very important for understanding its success of more than 225 million years. A detailed muscular reconstruction of given taxa may help to resolve specific points and may also contribute to understanding major transformations that took place between basal and avian dinosaurs.

Detailed EPB-based reconstructions of the pelvic and hind limb musculature of specific taxa have been provided for only two species: Tyrannosaurus rex (see Carrano and Hutchinson 2002) and Saturnalia tupiniquim (see Langer 2003). The work of Langer (2003) represents the most detailed muscular reconstruction for a basal dinosaur, and the results were presented as representative of a general condition shared by basal dinosauriforms (e.g., Marasuchus and Pseudolagosuchus) and basal dinosaurs, such as Herrerasaurus, Staurikosaurus, Guaibasaurus and basal species of the groups Theropoda, Ornithischia and Sauropodomorpha (Langer 2003).

Remains of basal dinosaurs are often very incomplete or poorly preserved, which may lead to uncertainties when muscular reconstructions are attempted. Therefore, it is important to evaluate muscle arrangement in other basal dinosaurs in order to complement previous works. Also, the study of the pelvic and hind limb musculature in other basal dinosaurs may confirm the hypothesis of Langer (2003) of a shared general construction in several basal members of the group. In this work we propose a detailed reconstruction of the pelvic and hind limb musculature of the basal Saurischian Staurikosaurus pricei Colbert, 1970. This taxon represents one of the most complete basal dinosaurs found in south Brazil (Santa Maria Formation, Late Triassic, Rio Grande do Sul), and its remains may reveal important features for understanding the early evolution of locomotion in Dinosauria.

\section{ABBREVIATIONS}

\begin{tabular}{|c|c|}
\hline ar & adductor ridge (= linea aspera $)$ \\
\hline bs & brevis shelf \\
\hline C1-25 & $1^{\text {st }}$ to $25^{\text {th }}$ caudal vertebra \\
\hline D11-15 & $11^{\text {th }}$ to $15^{\text {th }}$ dorsal vertebra \\
\hline Aris & dorsal ridge of ischium \\
\hline EPB & Extant Phylogenetic Bracket \\
\hline ir & ischial ridge \\
\hline is & ischium \\
\hline it & ischial tuberosity \\
\hline lia & linea intermuscularis cranialis \\
\hline lip & linea intermuscularis caudalis \\
\hline M. & muscle \\
\hline Mm. & muscles \\
\hline mr1 & first medial iliac ridge \\
\hline nbbf & medial blade of the brevis fossa \\
\hline 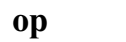 & obturator process \\
\hline & pubic apron \\
\hline
\end{tabular}




$\begin{array}{ll}\text { pf } & \text { preacetabular fossa } \\
\text { pib } & \text { preacetabular iliac border } \\
\text { pst } & \text { processus supratrochantericus } \\
\text { pt } & \text { pubic tubercle } \\
\text { pu } & \text { pubis } \\
\text { rea } & \text { rough expanded area } \\
\text { S1-2 } & 1^{\text {st }} \text { and } 2^{\text {nd }} \text { sacral vertebra } \\
\text { str } & \text { striations }\end{array}$

\section{MATERIALS AND METHODS}

In order to determine the areas of origin and insertion of the pelvic and hind limb muscles of Staurikosaurus pri$c e i$, the holotype MCZ 1669, deposited at the Museum of Comparative Zoology (Harvard University), as well as its cast (MN 6104-V), deposited at the Museu Nacional (Universidade Federal do Rio de Janeiro), were examined.

Firstly, based on recent studies on the evolution of the archosaur pelvic and hind limb osteology (Gatesy 1990, Hutchinson 2001a, b, 2002), the homologies between bone surfaces correlated with muscle attachments, were traced between extant taxa (Crocodylia and Aves) and Staurikosaurus. In this study we accept the general conclusion that Staurikosaurus was a herrerasaurid, which is considered as a basal saurischian (Fig. 1A) according to most recent works (Yates 2003, Langer 2004, Leal et al. 2004, Bittencourt and Kellner 2009). Additional osteological data were obtained from the direct examination of specimens from the osteological collection of the Museu Nacional, namely: Tupinambis sp. (Squamata, Teiidae; 04AC), Caiman yacare (Crocodylia, Crocodylidae; 05AC, 06AC and 07AC) and Dendrocygna viduata (Aves, Anseriformes, Anatidae; 14AC). Data was also gathered from the literature for the following taxa: fossils and living Crurotarsi (Gregory and Camp 1918, Romer 1923c, Troxell 1925, Parrish 1987, Long and Murry 1995, Galton 2000, Schwarz and Salisbury 2005), Dinosauromorpha and basal dinosaurs, including Herrerasauridae (Novas 1992, 1993, 1996, Sereno and Arcucci 1993, 1994, Long and Murry 1995, Bonaparte 1996, Hunt et al. 1998, Bonaparte et al. 1999), non-avian Theropoda (Osborn 1905, 1916, Ostrom 1969, Brinkman and Sues 1987, Paul 1988, 2002, Colbert 1989, Barsbold and Osmólska 1990, Bonaparte et al. 1990, Molnar et al. 1990, Nor- man 1990, Raath 1990, Rowe and Gauthier 1990, Madsen 1993, Makovicky and Sues 1998, Sampson et al. 1998, Norell and Makovicky 1999, Currie 2000, Carrano and Hutchinson 2002, Carrano et al. 2002, Currie and Chen 2001, Ji et al. 2003, Kobayashi and Lü 2003, Calvo et al. 2004, Huang et al. 2004, Naish et al. 2004, Coria and Currie 2006, Xu et al. 2006), Sauropodomorpha (Osborn 1904, Galton 1984, Ostrom and McIntosh 1999, Langer 2003, Yates 2003, Leal et al. 2004), and other extinct and extant sauropsid taxa, including Aves (Romer 1922, 1956, Goodrich 1958, Zaaf et al. 1999, Russell and Bels 2001, Paul 2002, Sen 2003, Clarke 2004).

The phylogenetic framework adopted here (Fig. 1A) is congruent with the tree used by Hutchinson (2001a, b, 2002) and those of Benton and Clark (1988), Benton (1999), Sereno (1997, 1999), Holtz (1998), Padian et al. (1999), Norell et al. (2001), Huang et al. (2004), Leal et al. (2004), Lloyd et al. (2008), and phylogenies presented in several of the works cited in the previous paragraph.

In order to define the correlations between bone surfaces and muscle origins and insertions we applied the Extant Phylogenetic Bracket (EPB) methodology (Witmer 1997). EPB allows the use of data from two (or more) extant taxa, which represent the closest groups to a given extinct taxon, in order to infer about the latter with minimal speculation, i.e., with parsimony (Fig. 1B). One of the extant taxa needs to be the living sister group of the extinct taxon, and this branch needs to have the other extant taxon as the living sistergroup. EPB was applied to verify the congruence of the reconstruction for each muscle of Staurikosaurus. As for any non-avian dinosaur, its closest extant taxa are Crocodylia and Aves (Fig. 1B). EPB was applied with the use of an extensive phylogenetic framework of fossil taxa, which facilitates the identification of homologies when the extant taxa are highly divergent, as is the case with Crocodylia and Aves.

We adopted the "levels of inference" of the EPB as a metric of the level of speculation in the soft tissue reconstruction, according to Witmer $(1995,1997)$.

We adopted the muscle homologies for Crocodylia and Aves (Table I) presented by Hutchinson (2001a, b, 2002) and Carrano and Hutchinson (2002) that corre- 

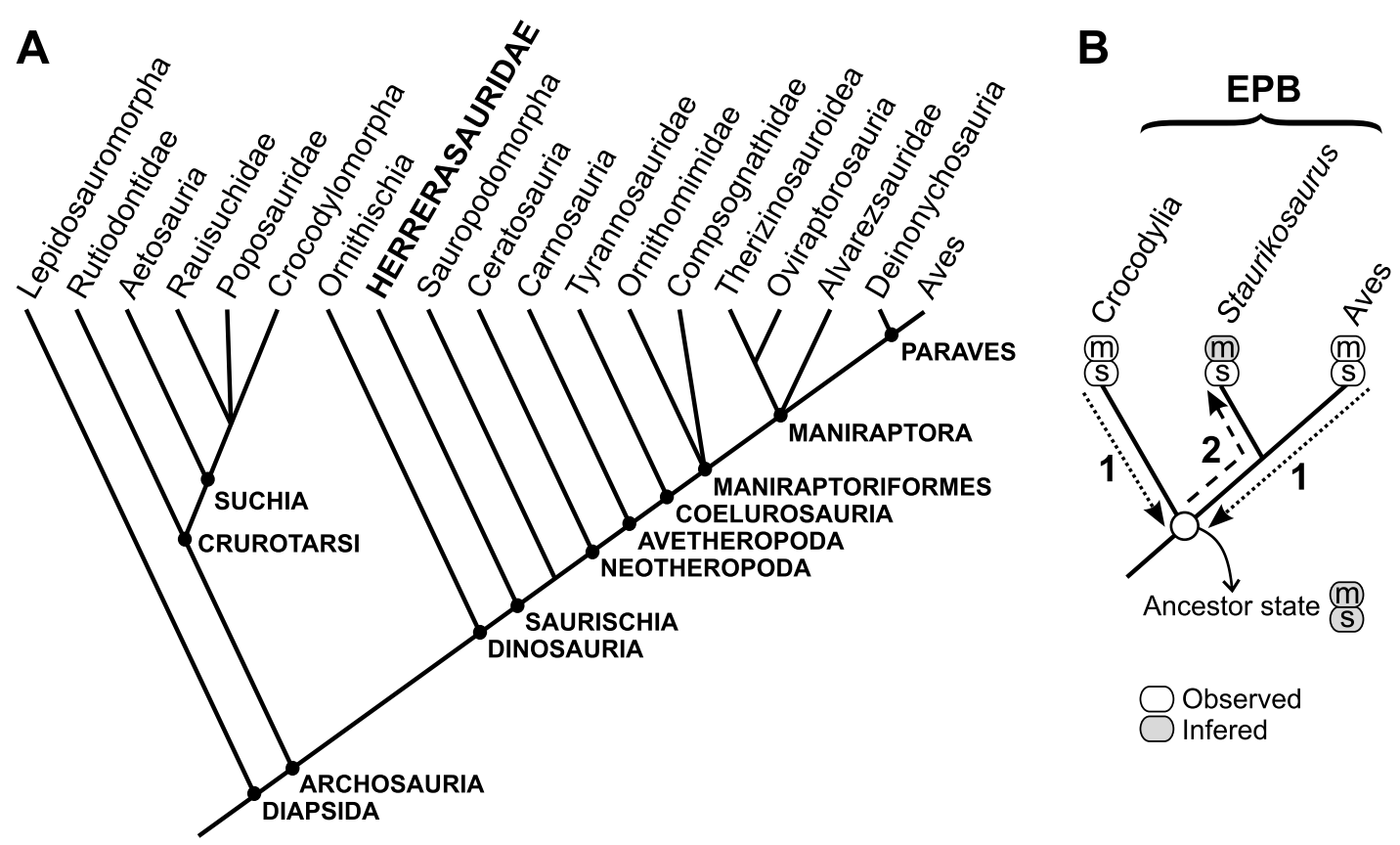

Fig. 1-Phylogenetic framework adopted in this study, depicting the position of Herrerasauridae (A) and the application of the EPB to Staurikosaurus muscle reconstruction (B): (1) Inference of the status of the osteological structure (s) and muscle (m) in the closest common ancestor of the extant taxa from the observation of the extant taxa; (2) if the inference indicates that the muscle was present in the ancestor, the most parsimonious condition indicates that it was also present in the extinct taxon (Staurikosaurus). Inferences are shown in gray circles (adapted from Witmer 1997).

spond to a revision of the work of Gadow (1880), Romer (1923c) and Rowe (1986).

\section{RESULTS}

The reconstruction of the pelvic and hind limb musculature of Staurikosaurus will be presented following the order on Table I. For each muscle, the condition observed in Crocodylia and Aves will be presented along with the preserved osteological evidence that supports the inferences for Staurikosaurus. The final reconstruction is presented in Table II and Figure 2.

\section{TRICEPS FEMORIS}

Mm. iliotibiales (IT1, IT2 and IT3) - Muscle (M.) iliotibialis is a superficial, thin, large lamina in Crocodylia and Aves, and is composed of three heads that originate along the anterior and dorsal margins of the lateral ilium (Romer 1923c, Carrano and Hutchinson 2002), superficially to other thigh muscles (Hutchinson 2002).

Langer (2003) noted a rough expanded area (rea) in the anterodorsal surface of the cranial iliac process in Saturnalia that he supposed to be homologous with an expanded area in Herrerasaurus, Caseosaurus, and other dinosaurs (Fig. 2 and 3F). This is continuous with the dorsal border of the ilium and was reconstructed as the origin of IT1 (Langer 2003).

This rough expanded area is also present, although less expanded, in other Diapsida, including Lepidosauromorpha. It seems correlated with the preacetabular iliac border (pib) because it is always adjacent to the dorsal extremity of that structure (Fig. 3). In some Suchia (Poposauridae and Rauisuchidae), the rough expanded area and the preacetabular iliac border are posteriorly dislocated along the lateral surface of the ilium, projecting over the supra-acetabular crest (Fig. 3D-F). Apparently, this condition is also present in Crocodylomorpha, as can be observed in the material from extant crocodiles, although an analysis of basal crocodiliforms is necessary to confirm the series of transformations between these taxa. In living crocodiles this rough area is less defined than in Poposauridae and Rauisuchidae and is not correlated to the origin of IT1, but corresponds to part of the area of IT2 (Fig. 3F). This rough area 


\section{TABLE I}

Homologies of the hind limb muscles in extant archosaurs (Modified from Hutchinson [2001a, 2002] and Carrano and Hutchinson [2002]). Although some variability exists within birds and crocodilians regarding muscle size, shape, and even presence, the condition listed represents the inferred condition for the common ancestor of each group (Carrano and Hutchinson 2002).

\begin{tabular}{|c|c|}
\hline Crocodylia & Aves \\
\hline \multicolumn{2}{|l|}{ DORSAL GROUP } \\
\hline \multicolumn{2}{|l|}{ 1. Triceps femoris } \\
\hline M. iliotibialis 1 (IT1) & M. iliotibialis cranialis (IC) \\
\hline Mm. iliotibiales 2, 3 (IT2, IT3) & M. iliotibialis lateralis (IL) \\
\hline M. ambiens (AMB) & M. ambiens (AMB) \\
\hline M. femorotibialis externus (FMTE) & M. femorotibialis lateralis (FMTL) \\
\hline M. femorotibialis internus (FMTI) & $\begin{array}{l}\text { M. femorotibialis intermedius (FMTIM) } \\
\text { and M. femorotibialis medialis (FMTM) }\end{array}$ \\
\hline M. iliofibularis (ILFB) & M. iliofibularis (ILFB) \\
\hline \multicolumn{2}{|l|}{ 2. Deep Dorsal } \\
\hline M. iliofemoralis (IF) & $\begin{array}{l}\text { M. iliofemoralis externus (IFE) } \\
\text { and M. iliotrochantericus caudalis (ITC) }\end{array}$ \\
\hline M. puboischiofemoralis internus 1 (PIFI1) & M. iliofemoralis internus (IFI) \\
\hline M. puboischiofemoralis internus 2 (PIFI2) & $\begin{array}{l}\text { M. iliotrochantericus cranialis (ITCR) } \\
\text { and M. iliotrochantericus medius (ITM) }\end{array}$ \\
\hline \multicolumn{2}{|l|}{ VENTRAL GROUP } \\
\hline \multicolumn{2}{|l|}{ 3. Flexor cruris } \\
\hline M. puboischiotibialis (PIT) & [absent] \\
\hline M. flexor tibialis internus 1 (FTI1) & [absent] \\
\hline M. flexor tibialis internus 2 (FTI2) & [absent] \\
\hline M. flexor tibialis internus 3 (FTI3) & M. flexor cruris medialis (FCM) \\
\hline M. flexor tibialis internus 4 (FTI4) & [absent] \\
\hline M. flexor tibialis externus (FTE) & M. flexor cruris lateralis pars pelvica (FCLP) \\
\hline \multicolumn{2}{|l|}{ 4. Mm. adductores femores } \\
\hline M. adductor femoris 1 (ADD1) & M. puboischiofemoralis pars medialis (PIFM) \\
\hline M. adductor femoris 2 (ADD2) & M. puboischiofemoralis pars lateralis (PIFL) \\
\hline \multicolumn{2}{|l|}{ 5. Mm. puboischiofemorales externi } \\
\hline M. puboischiofemoralis externus 1 (PIFE1) & M. obturatorius lateralis (OL) \\
\hline M. puboischiofemoralis externus 2 (PIFE2) & M. obturatorius medialis (OM) \\
\hline M. puboischiofemoralis externus 3 (PIFE3) & [absent] \\
\hline 6. M. ischiotrochantericus (ISTR) & M. ischiofemoralis (ISF) \\
\hline \multicolumn{2}{|l|}{ 7. Mm. caudofemorales } \\
\hline M. caudofemoralis brevis (CFB) & M. caudofemoralis pars pelvica (CFP) \\
\hline M. caudofemoralis longus (CFL) & M. caudofemoralis pars caudalis (CFC) \\
\hline
\end{tabular}

and the preacetabular iliac border are also adjacent to the anterior limit of the M. iliofemoralis (Fig. 3F), as seen in Lepidosauromorpha (Fig. 3A).

The hypothesis presented by Langer (2003) is incongruent with these observations, so we propose that this rough expanded area is related to IT2 so that the an- terior part of the origin of this muscle should be ventral to IT1 in dinosaurs, as occurs in Alligator (Fig. 3F).

The rough area is preserved in both ilia of Staurikosaurus and is located in the extremity of the preacetabular iliac border (Fig. 4C). It is triangular in shape, similar to the rough area of Caseosaurus (Fig. 4G). In 
TABLE II

Muscles inferred as present in Staurikosaurus pricei and levels of inference required.

\begin{tabular}{|c|c|c|}
\hline Muscle & Origin & Insertion \\
\hline IT1 & $\begin{array}{l}\text { anterodorsal border of the ilium (I), in a rough } \\
\text { expanded area (are) }\end{array}$ & tibial cnemial crest (I) \\
\hline IT2 & dorsal border of the ili um (I); posterior limit undefined & tibial cnemial crest $(\mathrm{I})$ \\
\hline IT3 & $\begin{array}{l}\text { dorsal border of the ilium (I); posterior limit between } \\
\text { ILFB and FTE (I') }\end{array}$ & tibial cnemial crest (I) \\
\hline$A M B$ & pubic tubercle (I) & tibial cnemial crest $(\mathrm{I})$ \\
\hline FMTE & lateral surface of femoral shaft, between lia and lip (I) & tibial cnemial crest (I) \\
\hline FMTI & lateral surface of femoral shaft, between lia and ar (I) & tib ial cnemial crest (I) \\
\hline ILFB & $\begin{array}{l}\text { concavity on the lateral postacetabular surface of the } \\
\text { ilium (l') }\end{array}$ & crest in the anterolateral margin of the fibula (I) \\
\hline IFE & $\begin{array}{l}\text { subtriangular concavity on the lateral surface of the } \\
\text { ilium (I), posterior to ITC (II) }\end{array}$ & femoral trochanteric shelf (II) \\
\hline ITC & $\begin{array}{l}\text { subtriangular concavity on the lateral surface of the } \\
\text { ilium (I), anterior to IFE (II) }\end{array}$ & anterior trochanter (II) \\
\hline PIFI1 & $\begin{array}{l}\text { ? - medial surface of the ilium and in the sacral ribs } \\
\text { (II) or in the iliac "preacetabular fossa" (II) }\end{array}$ & $\begin{array}{l}\text { me dial surface of the anteromedial proximal } \\
\text { keel of the femur (II) }\end{array}$ \\
\hline $\mathrm{PIFI}$ & last five (six?) dorsal verteb rae (II) & $\begin{array}{l}\text { lateral surface of the anteromedial proximal kee } \\
\text { of the femur (II); posterior tendon absent? }\end{array}$ \\
\hline PIT & [probably absent] & [prob ably absent] \\
\hline FTI1 & $\begin{array}{l}\text { if present, in the distal ischial tubercle (not preserved; } \\
\text { II') }\end{array}$ & $\begin{array}{l}\text { if present, on a mark in the proximal } \\
\text { caudomedial surface of the tibia (II) }\end{array}$ \\
\hline $\mathrm{FTI} 2$ & $\begin{array}{l}\text { lateral postacetabular surface of the ilium, posterior to } \\
\text { FTE (II') }\end{array}$ & $\begin{array}{l}\text { scar in the proximal caudomedial surface of the } \\
\text { tibia (II) }\end{array}$ \\
\hline FTI3 & ischial tuberosity (II) and adjacent concavity (?) & $\begin{array}{l}\text { scar in the proximal medial surface of the tibia } \\
\text { (I) }\end{array}$ \\
\hline FTI4 & ? & ? \\
\hline FTE & $\begin{array}{l}\text { lateral postacetabular surface of the ilium, posterior to } \\
\text { ILFB (l') }\end{array}$ & $\begin{array}{l}\text { scar in the proximal medial surface of the tibia } \\
\text { (I) }\end{array}$ \\
\hline ADD1 & $?$ - anterior margin of the ischial obturator process $\left(\mathrm{I}^{\prime}\right)$ & $\begin{array}{l}\text { posterior surface of the femoral shaft, between } \\
\text { lip and } \operatorname{ar}(\mathrm{I})\end{array}$ \\
\hline ADD2 & $\begin{array}{l}\text { scar on the lateral surface of the ischium, dorsal to the } \\
\text { ischiadic border (II) }\end{array}$ & $\begin{array}{l}\text { posterior surface of the femoral shaft, between } \\
\text { lip and } \operatorname{ar}(\mathrm{I})\end{array}$ \\
\hline PIFE1 & anterior surface of the pubic apron (II) & femoral greater trochanter $(\mathrm{I})$ \\
\hline PIFE2 & posterior surface of the pubic apron (II) & femoral greater trochanter $(I)$ \\
\hline PIFE3 & $\begin{array}{l}\text { caudoventral to the ischiadic border, between ADD1 } \\
\text { and ADD2, on the lateral surface of the obturator } \\
\text { process (II) }\end{array}$ & femoral greater trochanter $(\mathrm{I})$ \\
\hline ISTR & $\begin{array}{l}\text { medial and dorsal surfaces of the ischium, adjacent to } \\
\text { ADD2 (II) }\end{array}$ & $\begin{array}{l}\text { proximal lateral surface of the femur (I), in a } \\
\text { groove proximal to the trochanteric shelf }\end{array}$ \\
\hline CFB & expanded medial surface of the iliac brevis fossa (II) & $\begin{array}{l}\text { posterior lateral surface of the femur, between } \\
\text { the fourth tro chanter and /ip (I) }\end{array}$ \\
\hline CFL & $\begin{array}{l}\text { caudal vertebral centra and transverse processes (at } \\
\text { least from } 1 \text { to } 25 ; \mathrm{I} \text { ) }\end{array}$ & $\begin{array}{l}\text { me dial surface of the fourth trochanter (I); } \\
\text { secondary tendon absent (II) }\end{array}$ \\
\hline
\end{tabular}

Herrerasaurus, differently, this area is larger in the ventral part, a condition also seen in Marasuchus. In Staurikosaurus, the origin of IT1 is supposedly located in the anterolateral margin of the cranial iliac process (Level I inference), in the dorsal portion of the rough area. The origin of IT2 extends along the ventral portion of this surface and continues to the dorsal margin of the ilium. The dorsal iliac border is not preserved in Staurikosaurus, so it is impossible to determine the exact limit between IT2 and IT3. Likewise, the posterior limit of IT3 is not observable, but, in Crocodylia, it is located dorsal to the origin of M. flexor tibialis externus (FTE) and caudal to the origin of M. iliofibularis (ILFB; Fig. 2A).
In Aves, the posterior limit of M. iliotibialis lateralis $(\mathrm{IL}=\mathrm{IT} 2+3)$ is located between the areas of origin of M. flexor cruris lateralis pars pelvica $(\mathrm{FCLP}=\mathrm{FTE})$ and ILFB (Fig. 2C). Accordingly, it is possible to infer the posterior limit of IT3 in Staurikosaurus from the position of ILFB and FTE (Level I' inference).

In living archosaurs, the three heads of M. iliotibialis converge together with M. ambiens and Mm. $f e-$ morotibiales, forming a common extensor tendon that inserts onto the tibial cnemial crest (Romer 1923c, Hutchinson 2002, Carrano and Hutchinson 2002). The same condition is inferred for Staurikosaurus (Level I inference). 


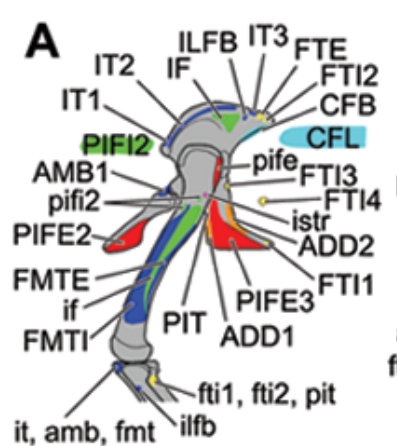

E
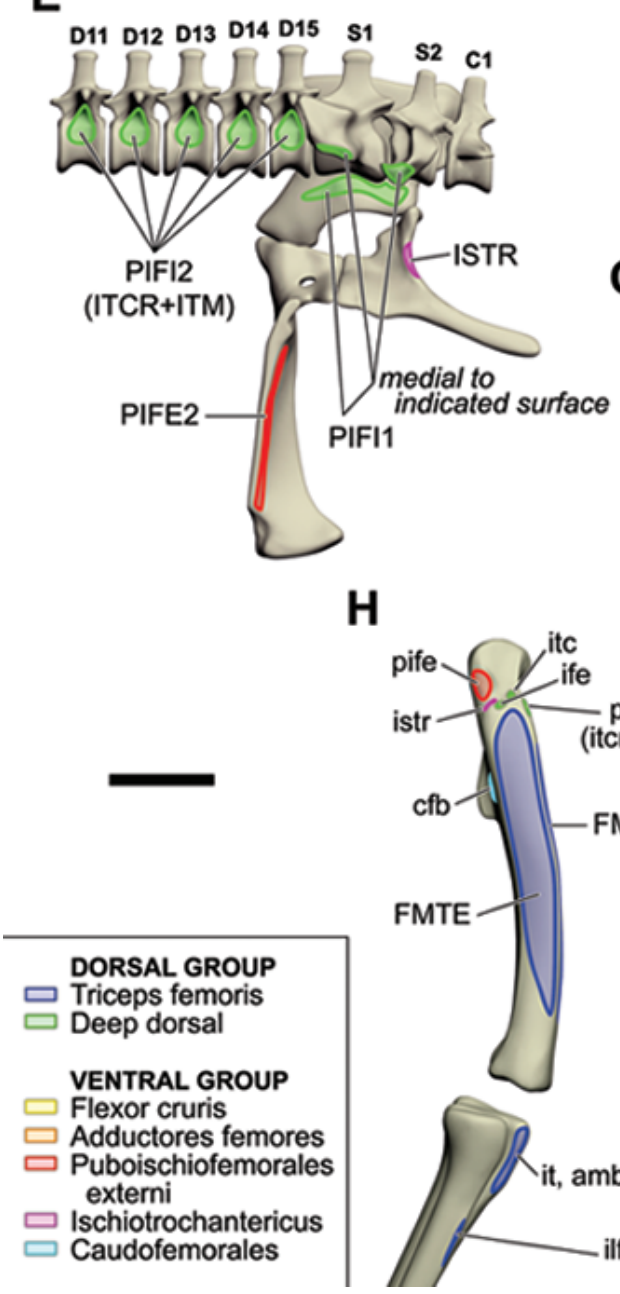

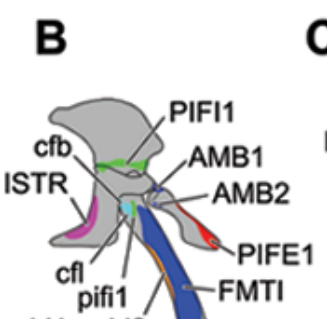

add1, add2 $\mathrm{fti3}$, fti4, fte

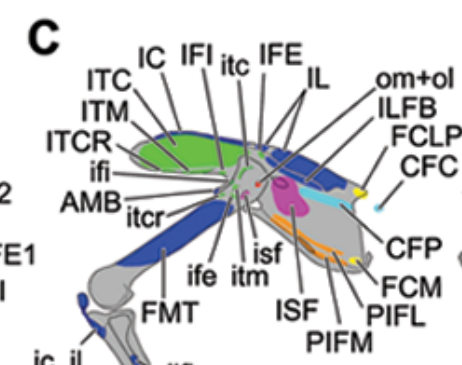

amb, fmt

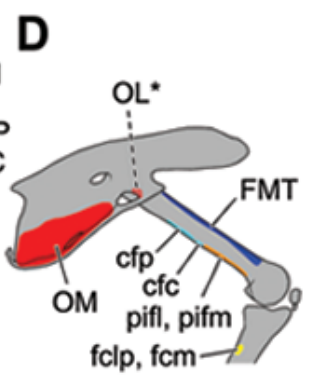

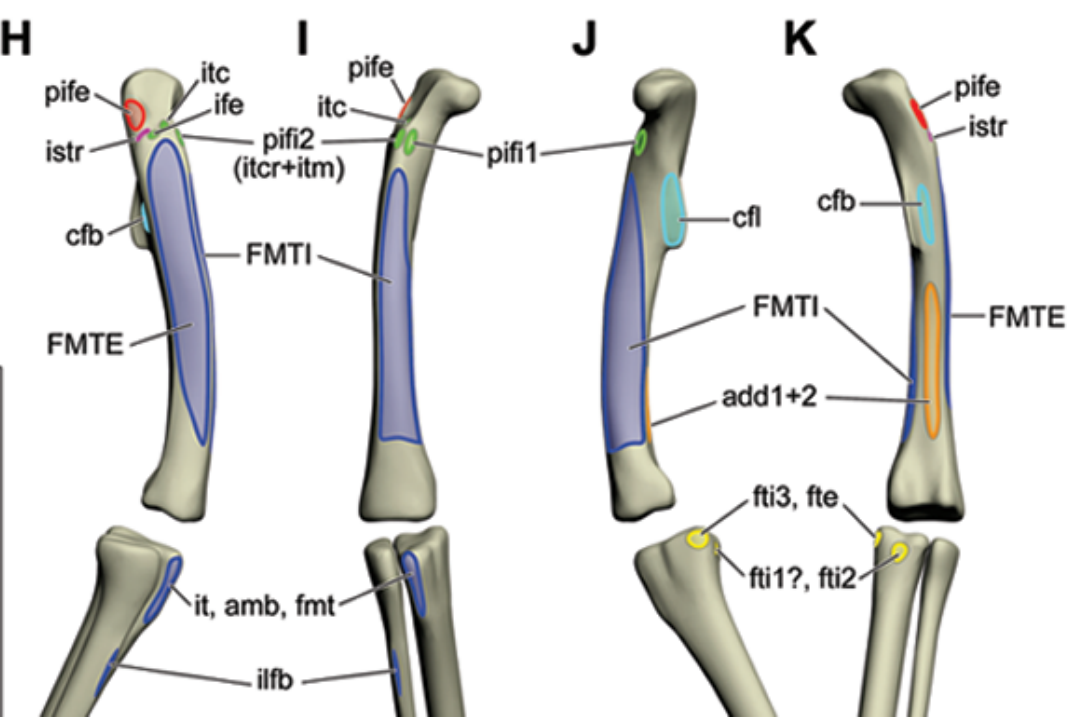

Fig. 2 - Areas of muscle origin (upper case) and insertion (lower case) in extant Crocodylia (A and B) and Aves (C and D), and proposed reconstruction for Staurikosaurus indicated over a 3D reconstruction of the pelvis and vertebrae (E-G) and hind limb (H-K). Lateral view (A, C, F, H), medial view (B, D, E, J), anterior view (G, I) and posterior view (K). In G, it is shown the two possibilities for the origin of PIFI1. Abbreviations followed by question mark indicate uncertain presence of the muscle or uncertain position on the area indicated (no clear scar was observed). The asterisk in D indicates that the origin of the muscle occurs on the opposite side of the indicated surface. Dashed lines in $\mathrm{F}$ indicate uncertain position of the division of the areas of origin of IFE and ITC or IT1 and IT2. Scale bars: 50 mm (A-D modified from Carrano and Hutchinson 2002). 
M. ambiens (AMB) - In extant Reptilia (including Aves), the origin of the M. ambiens is anteroventral to the acetabulum, often from a pubic tubercle ( $p t$; Hutchinson 2001a). In Crocodylia, this structure is absent or reduced (Hutchinson 2001a), and M. ambiens is divided in two heads that originates on the cranial portion of the preacetabular cartilage and in the medial proximal region of the proximal pubis, but this condition is derived in relation to other Reptilia (Romer 1923c, Hutchinson 2002). The pubic tubercle of Staurikosaurus is preserved only on the left pubis (Fig. 5A) and is similar in shape to that of Herrerasaurus, Saturnalia, and Lagerpeton. The right pubis of Staurikosaurus has often been used to illustrate this bone in the taxon, but it is damaged in the region of the pubic tubercle. This leaded several authors (e.g., Colbert 1970, Galton 1977, Novas 1993) to propose that this structure was absent in Staurikosaurus. AMB inserts in the tibial cnemial crest, together with the Triceps femoris group (Romer 1923c, Hutchinson 2002). In extant archosaurs, AMB also has a secondary tendon that perforates the extensor tendon (Carrano and Hutchinson 2002, Hutchinson 2002). This tendon was probably also present in Staurikosaurus.

Mm. femorotibiales (FMTE and FMTI) - M. femorotibialis has two divisions in Crocodylia (femorotibialis externus, FMTE; femorotibialis internus, FMTI) and three in Aves (femorotibialis lateralis, FMTL; femorotibialis intermedius, FMTIM; femorotibialis medialis, FMTM), which originates from the main part of the femoral shaft between the trochanteric region and the condyles (Romer 1923c, Hutchinson 2002, Carrano and Hutchinson 2002). Three ridges (linea intermuscularis cranialis, lia; linea intermuscularis caudalis, lip ; linea aspera $=$ adductor ridge, ar) indicate the limits between these muscles, defining three adjacent areas around the femoral shaft: FMTE (= FMTL) is delimited by lia and lip, and FMTI (= FMTIM + FMTM) is limited by lia and ar (Hutchinson 2001b). In Staurikosaurus these three ridges are not complete, but the right femur and the proximal part of the left femur have the major part of the lip and its distal part respectively preserved. An irregular border is seen on the middle anterior portion of the left femur, exactly in the position where lia of Herrerasaurus is located (Hutchinson 2001b). The distal part of ar can be observed on the right femur of
Staurikosaurus, but most of its dorsal extension is obliterated due to distortions of the fossil. In the left femur, this portion of the shaft is concealed by the dorsal vertebrae. Accordingly, it is possible to determine the areas of origin of FMTE and FMTI with some precision, but their exact distal extension is uncertain.

In Aves, FMTI is divided in two parts (FMTIM and FMTM). Langer (2003) observed in Saturnalia a tenuous line that extends proximally from the medial condyle along the medial surface of the femur that could indicate a rudimentary division of FMTI. Due to poor preservation, this structure is not observable in Staurikosaurus.

As in extant Archosauria, Mm. femorotibiales of Staurikosaurus extended anterolaterally down to the proximal tibia, where they inserted onto the anterolateral cnemial crest, forming the knee extensor tendon (Romer 1923c, Carrano and Hutchinson 2002).

M. iliofibularis (ILFB) - M. iliofibularis originates on the lateral surface of the ilium, between Mm. iliofemoralis and flexor tibialis externus (Hutchinson 2002, Carrano and Hutchinson 2002), slightly ventral to iliotibialis (Romer 1923c). Bittencourt and Kellner (2009) indicated that Staurikosaurus has one large concavity on the lateral surface of the ilium, but, this concavity appears to be divided in two by a smooth elevation (Fig. 4A-B), so that two concavities are present. The anterior one is large and deep and is located just dorsal to the acetabulum. The shallower posterior concavity probably corresponds to the ILFB origin because it is topographically equivalent to the surface where this muscle originates in extant Archosauria. A smooth arcshaped scar in the dorsoposterior limit of the posterior concavity may indicate the limits of ILFB origin (Fig. $4 \mathrm{C}$ ), whereas its ventral limit is indicated by the brevis shelf (Fig. 4C).

The anterolateral surface of the proximal part of the fibula of Staurikosaurus has an elongated crest that corresponds to the ILFB tubercle (Bittencourt and Kellner 2009), i.e., the insertion area of ILFB, as seen in extant Archosauria.

\section{DEEP DORSAL}

M. iliofemoralis externus (IFE) and M. iliotrochantericus caudalis (ITC) - In Crocodylia the M. iliofemoralis (IF) is not divided, but in Aves it has two parts: 

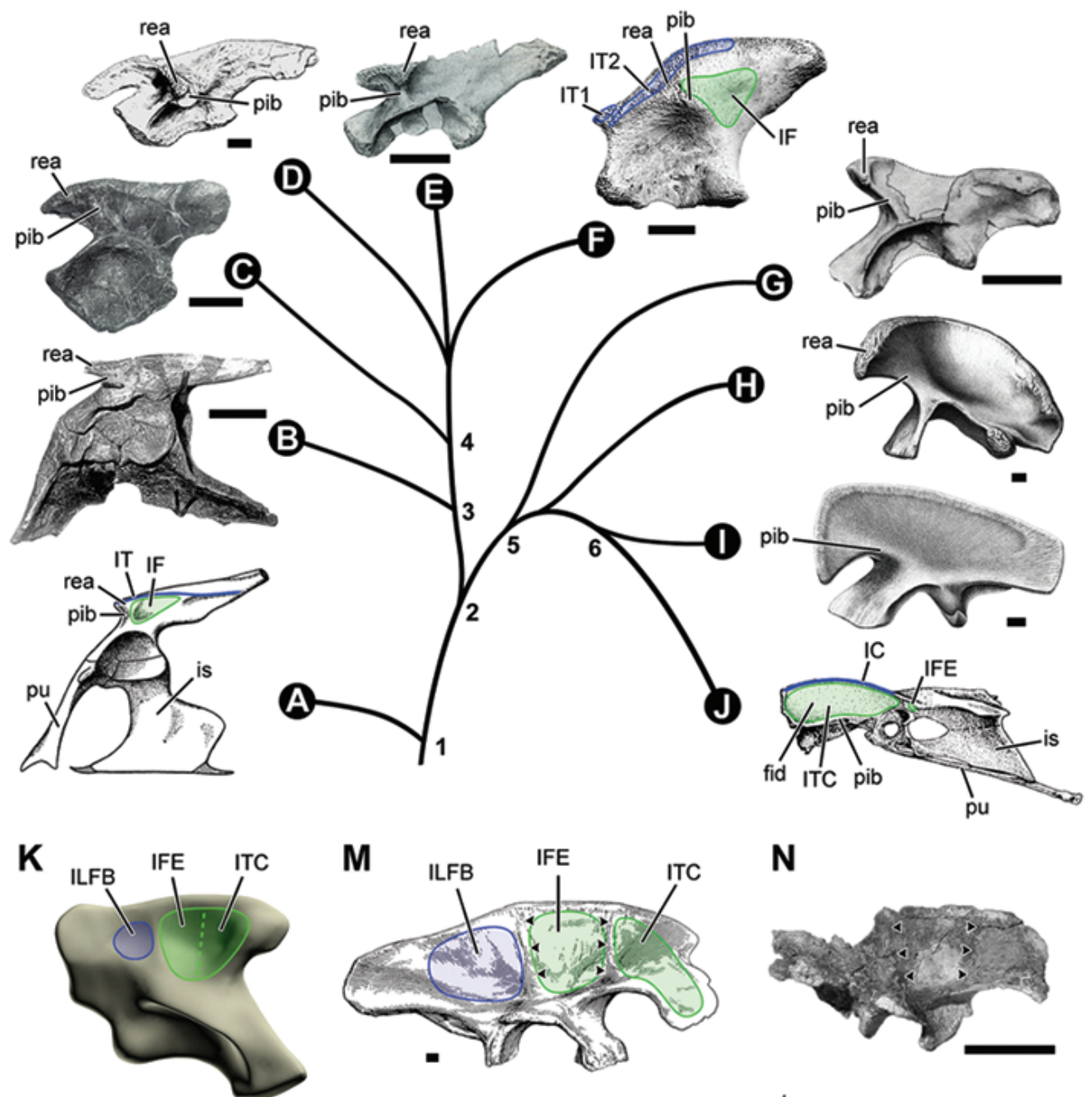

$\mathbf{N}$
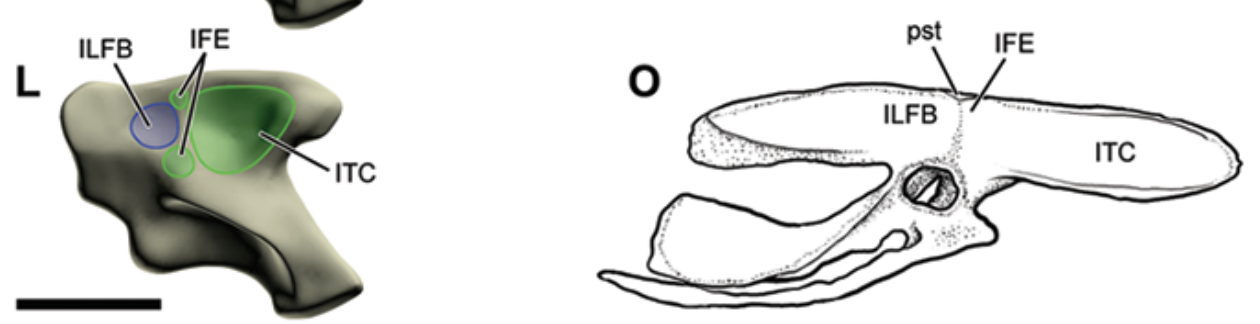

Fig. 3 - Iliac structures associated with muscle origin. A-J: Evolution of the preacetabular iliac border ( $p i b)$ and the associated rough expanded area (rea) in Diapsida and its relationship with the origin of the muscles IT, IC (blue areas in A, F and J) and IF, IFE and ITC (green areas in A, F, and J). Number and letters correspond to the following taxa: (1) Diapsida (A - Iguana, Lepidosauromorpha), (2) Archosauria, (3) Crurotarsi (B Leptosuchus, Rutiodontidae), (4) Suchia (C-Stagonolepis, Aetosauria; D-Lythrosuchus, Poposauridae; E-Postosuchus [juvenile], Rauisuchidae; F-Caiman, Crocodylomorpha), (5) Saurischia (G - Caseosaurus, Basal Saurischia [right ilium reversed]; H - Apatosaurus, Sauropodomorpha) and (6) Avetheropoda (I - Allosaurus, Carnosauria; J - Meleagris, Aves). K-O: Relationship between the position of the areas of origin of ITC, IFE and ILFB in Staurikosaurus (K, hypothesis adopted in this work; L, two hypothesis proposed by Langer 2003), Tyrannosaurus (M), Sinornithomimus $(\mathrm{N})$ and Crypturellus $(\mathrm{O}$, indicating the relationship of IFE and the processus supratrochantericus, $p s t)$. Arrowheads in M and $\mathrm{N}$ indicate the convex borders that may indicate anterior and posterior limits of IFE. Scale bars: $50 \mathrm{~mm}$ (A - after Romer 1922, 1923c, 1956; B-E and G - from Long and Murry 1995; F - muscle disposition according to Romer 1923c; H - from Ostrom and McIntosh 1999; I - from Madsen 1993; J, O - from Hutchinson 2001a; M - from Osborn 1916; N - from Kobayashi and Lü 2003). 
iliofemoralis externus (IFE) and iliotrochantericus caudalis (ITC) (Carrano and Hutchinson 2002). This subdivision is reflected on a differentiation in the area of insertion of IF in the femoral trochanteric shelf: in Dinosauriformes, the trochanteric shelf has a cranial protuberance (anterior or lesser trochanter) that is homologous to the area of insertion of ITC in Aves, which suggests that IF was divided in this taxon (Hutchinson 2001b). This structure is present in Staurikosaurus, but is reduced in size (Bittencourt and Kellner 2009), so we can infer the presence of both IFE and ITC and indicate the area of insertion of ITC.

According to Hutchinson (2002), the insertion of IFE occurs in a rough area of the trochanteric shelf, on the lateral surface of the femur. In the left femur of Staurikosaurus there are some rough scars with undefined limits that may correspond to muscle insertion areas (Fig. 5D). One of these is located on the trochanteric shelf, exactly posterior to the anterior trochanter, and is interpreted here as the insertion area of IFE.

IFE and ITC origins are located on the lateral surface of the ilium, but there is generally no scars that indicate the exact limits of their areas (Hutchinson 2001a, Carrano and Hutchinson 2002). As already mentioned, the ilium of Staurikosaurus has a large subtriangular concavity on the anterior lateral surface of the ilium. This is dorsal to the acetabulum, bound anteriorly by the preacetabular iliac border (Fig. 4C). This concavity could hold a large muscle, similar to the condition observed in Tyrannosaurus by Carrano and Hutchinson (2002) and in Saturnalia by Langer (2003). A Level I inference indicates that this area corresponds to the origin of both parts of the iliofemoralis (IFE and ITC), contrary to the proposition of Langer (2003). According to Langer (2003), ITC would occupy this entire concavity and IFE would originate from the dorsal border of the acetabulum, immediately posterior to the supraacetabular crest or from a small surface in the dorsal limit between this large anterior concavity and the concavity of origin of ILFB (Fig. 3L). The first hypothesis is not congruent with the position of the origin of IFE in Aves because it is located between ITC and ILFB, and is immediately ventral to the muscle iliotibialis. Also, Carrano and Hutchinson (2002) noted a vertical ridge dividing the anterior cavity in two equally-sized areas in Tyrannosaurus, and they interpreted this as the division of IF in IFE and ITC (Fig. 3M). The similar size of these two muscles is corroborated by the size of their insertion areas in the femur. According to the propositions of Langer (2003), ITC would be a very large muscle and IFE would be a very small one, and this is not congruent with the size of their insertion areas in the femur of Staurikosaurus: the anterior trochanter is reduced and, although the limits of the insertion area of IFE are not clear, the rough area appears to be equal in size to the anterior trochanter (Fig. 5D).

The anterior limit of ITC may be indicated by the preacetabular iliac border that is adjacent to the anterior limit of the area of IF in lepidosaurs and Crocodylia, and of ITC in Aves (Fig. 3A, F, J). In Staurikosaurus, the preacetabular iliac border has striations (str) parallel to its long axis (Fig. 4C) that may be related to the origin of ITC.

M. puboischiofemoralis internus 1 (PIFI1)-M. puboischiofemoralis internus 1 of Crocodylia (= iliofemoralis internus, IFI, in Aves) is homologous to the muscles PIFI1 and PIFI2 of other Reptilia (Rowe 1986, Hutchinson 2002).

In Crocodylia, PIFI1 originates from the medial surface of the ilium, in the medial proximal surface of the ischium, and sacral ribs (Romer 1923c, Hutchinson 2001a, 2002, Carrano and Hutchinson 2002). In Aves, IFI originates on the lateral surface of the ilium, from a reduced preacetabular (“cuppedicus") fossa ( $p f$; Hutchinson 2001a, 2002). The change in position of the origin area of PIFI1 can be observed along the evolution of Archosauria and is related to the expansion of the cranial iliac process (Carrano 2000, Hutchinson 2001a). The appearance of the preacetabular fossa and the reduction of the ventral portion of the pelvis also indicate this transition (Hutchinson 2001a, 2002). These changes probably produced the dorsolateral displacement of PIFI1 origin in tetanuran theropods (as indicated by the appearance of the preacetabular fossa). The lateral displacement in Aves is indicated by the reduction of this fossa (Norell et al. 2001, Hutchinson 2002).

In basal dinosaurs, including Staurikosaurus, there are few indications of these modifications. Compared to Neotheropoda, the ventral portion of the pelvis is well 


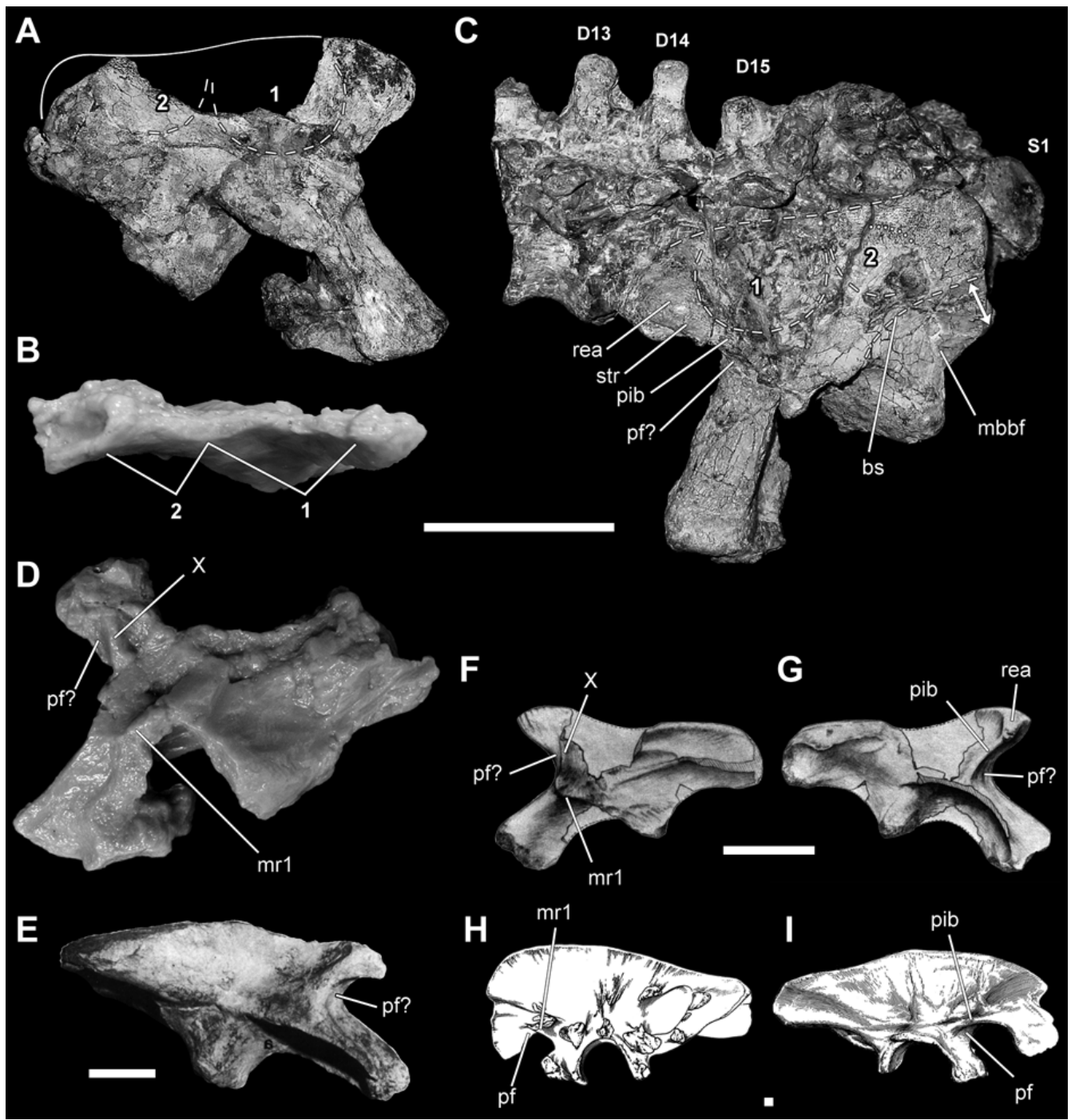

Fig. 4 - Right (A-B) and left (C) ilium of Staurikosaurus in lateral (A, C) and dorsal (B) views indicating the existence of two concavities (1 and 2) on the lateral surface and the expansion of the posterior part of the medial blade of the brevis fossa ( $m b b f)$, indicated by the two directions arrow (C). The dorsoposterior limit of ILFB origin (concavity 2) is indicated by a smooth border (dotted line in C). Right ilium of several taxa (D-I) indicating the presence of a preacetabular fossa $(p f)$ or a similar structure $(p f$ ?) on the ventral surface of the cranial iliac process: Staurikosaurus (medial view [D]), Sellosaurus (lateral view [E]), Caseosaurus (medial [F] and lateral [G] views) and Tyrannosaurus (medial [H] and lateral [I] views). The first medial iliac ridge ( $m r 1)$ delimits the preacetabular fossa medially in Tyrannosaurus. In Staurikosaurus and Caseosaurus, this fossa is delimited medially by a border $(X)$ connected, but not equivalent to the $m r 1$. Scale bars: $50 \mathrm{~mm}$ (E - from Galton 1984; F-G - from Long and Murry 1995; H-I - from Osborn 1916).

developed and the cranial process of the ilium is not expanded. Hutchinson (2001a) considers the preacetabular fossa as an Avetheropoda character formed by the expansion of the first medial iliac ridge (articulation ridge for the first sacral vertebra; $m r l$ ) that marks the medial limit of this fossa (Fig. 4H-I). In Caseosaurus and Stau- rikosaurus the first medial iliac ridge is in similar position to this border in Crocodylia, i.e., horizontal and just dorsal to the acetabulum (Fig. 4D, F, H). However, these two forms bear another medial ridge in the ilium that appears to represent a dorsal extension of the first medial iliac border and that also participates in the sacral ver- 
tebra articulation ( $X$ in Fig. 4D, G). This ridge bounds a shallow fossa, topographically equivalent to the preacetabular fossa, i.e., it is located in the ventromedial surface of the cranial process of the ilium (Fig. 4). Despite the topographical equivalence, the homology between these structures is not clear because this fossa is medially limited by a ridge that cannot be certainly homologized with the first preacetabular medial ridge of the ilium. Accordingly, the origin of PIFI1 in Staurikosaurus is uncertain (Fig. 2G): it could be equivalent to that of Crocodylia (Level II inference), or may have shifted into the aforementioned fossa (also Level II inference).

The PIFI1 of Crocodylia inserts at the proximal part of the femur, anteromedially to the insertions of PIFI2 (Romer 1923c, Hutchinson 2001b, 2002), on a keel that separates the insertion of PIFI2 and FMTI (Hutchinson 2001b). In Aves, IFI inserts on a rounded mark at the medial proximal portion of the femur (Hutchinson 2001b, 2002). Herrerasaurus (Novas 1993, Hutchinson 2001b) and Staurikosaurus possess a crest on the anterior surface of the femur, distal and anterior to the anterior trochanter, that is similar to that of Crocodylia, indicating a similar insertion of PIFI1 (Level II inference).

M. puboischiofemoralis internus 2 (PIFI2) - There are two homology hypothesis for the archosaur PIFI2 (Carrano and Hutchinson 2002, Hutchinson 2002): PIFI2 of Crocodylia may be homologous to Mm. iliotrochantericus cranialis (ITCR) and medius (ITM) of Aves (Romer 1923b, Rowe 1986), with M. iliofemoralis (IF) of Crocodylia divided in two avian parts: iliofemoralis externus (IFE) and iliotrochantericus caudalis (ITC); and PIFI2 may have been lost in Aves, and IF was divided in four parts: IFE, ITC, ITCR and ITM (Gadow 1880). Because the first hypothesis has more support from anatomical and ontogenetic data and requires fewer transformations in the number and position of muscles (Rowe 1986), we will treat PIFI2 of Crocodylia as homologous to ITCR and ITM of Aves. PIFI2 of Crocodylia should not be confused with the homonymous muscle of other Reptilia, but is homologous to their PIFI3 (Rowe 1986, Romer 1923b).

In Crocodylia, PIFI2 originates from the centra and transverse processes of the last six dorsal vertebrae (lum- bar vertebrae; Romer 1923c). In Aves, the origins of the homologous ITCR and ITM are located on the ventrolateral surface of the preacetabular iliac process, anteriorly to the origin of IFI. As previously presented, this transition is associated with the expansion of the preacetabular iliac process and with the origin of the preacetabular fossa (Hutchinson 2001a, 2002). In Tyrannosaurus, the centra of the dorsal vertebrae have large pleurocels and little area for the attachment of muscles, and the preacetabular fossa is present (Carrano and Hutchinson 2002). Staurikosaurus, on the other hand, has large areas for the attachment of PIFI2 on the dorsal vertebrae that lack pleurocels. Also, the last five dorsal vertebrae of Staurikosaurus have shallow depressions bellow the infradiapophyseal fossae that could correspond to part of PIFI2 origin. The eighth and ninth dorsal vertebrae are partly covered by sediments and rib fragments, so it is impossible to verify the presence of these depressions, which are absent from the seventh to the more anterior dorsal vertebrae. Accordingly, as for Crocodylia, PIFI2 of Staurikosaurus probably originated from the last five (maybe six) dorsal vertebrae (Level II Inference).

In Crocodylia, PIFI2 inserts on the lateral surface of a keel extending along the proximal femur, lateral to the PIFI1 insertion, and its tendon is partly divided by the proximal part of the origin of FMTI (Romer 1923c). In Tetanurae, PIFI2 inserts on a large process (accessory trochanter), which is reduced to a small scar in basal Aves (Hutchinson 2002). Despite this difference, the positions of these structures are the same. Bittencourt and Kellner (2009) proposed that, in Staurikosaurus, PIFI2 inserted on a proximodistally extended and narrow crest located on the posterolateral surface of the proximal femur, but it is not congruent with the position observed in Crocodylia and Aves. In fact, this crest corresponds to the medial limit of the insertion of Mm. puboischiofemorales externi.

In Staurikosaurus, the surface of the anterior keel of the femur is damaged and partly covered by sediments, and it is impossible to identify muscle scars. However, the same condition seen in Crocodylia, with PIFI2 inserting on the lateral surface of this keel, is likely to occur, since it is equivalent to the accessory trochanter (Level I' inference). It is not possible to confirm the presence of the posterior portion of the 


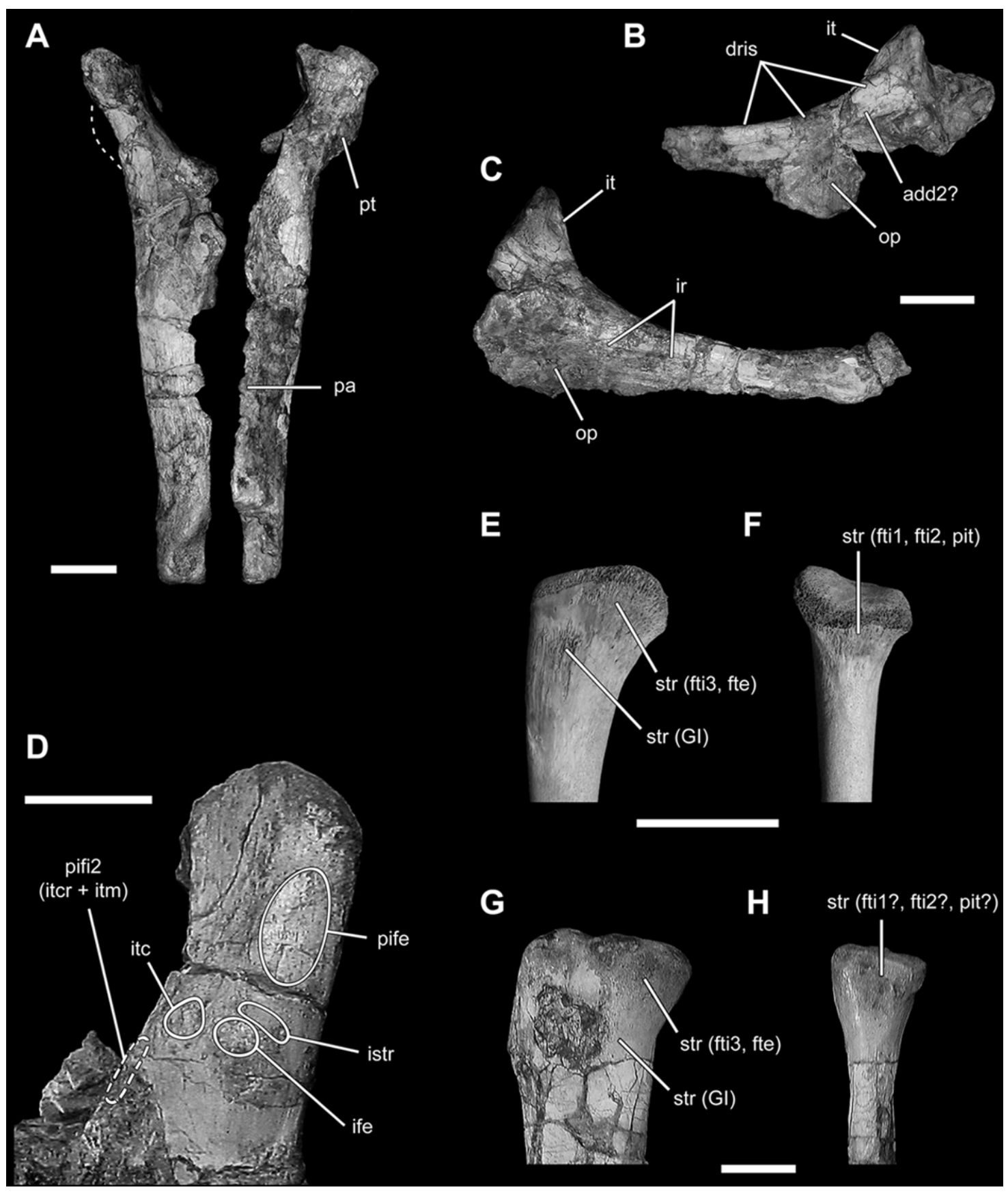

Fig. 5 - Right and left pubis in anterior view (A) indicating the pubic tubercle $(p t)$ and the pubic apron $(p a)$. Dashed line indicates the supposed position of the unpreserved pt in the right pubis. Right (B) and left (C) ischium in lateral view. The dorsal ridge of the ischium (dris), ischial ridge (ir), ischial tuberosity (it) and obturator process $(o p)$ are indicated, along with a scar that may indicate the origin of ADD2. Lateral view of the proximal part of the left femur (D) indicating the approximate areas of insertion of the muscles ITC (on the anterior trochanter), IFE (on the trochanteric shelf), ISTR (on a groove proximal to the trochanteric shelf) and PIFE (on the greater trochanter). The probable insertion of PIFI2 is also indicated (on the lateral surface of the anterior keel of the femur). Proximal part of the right tibia of Caiman (E and F) and Staurikosaurus (G and $\mathrm{H}$ ) in medial (E and $\mathrm{G}$ ) and posterior (F and H) views: the striations (str) in Staurikosaurus are topographically equivalent to the insertions of FTI1-3, FTE, PIT and gastrocnemius internus (GI) in Caiman. Scale bars: $20 \mathrm{~mm}$. 
insertion tendon in the currently available material of Staurikosaurus; the muscle scars on the trochanteric region of the femur are not well defined.

\section{FLEXOR CRURIS}

Homologies of the Flexor cruris group are not well resolved (Romer 1923c, Hutchinson 2002). Here we follow the hypothesis of Romer (1942). See Hutchinson (2002) for a revision of different hypothesis and nomenclature.

The Flexor cruris muscles share two insertion tendons in Crocodylia: FTI1 shares a tendon with FTI2 that connects to the tendon of PIT, and inserts on the caudomedial surface of the proximal tibia (Romer 1923c, Hutchinson 2002), whereas FTI3, FTI4 and FTE share a tendon that inserts on the posteromedial surface of the proximal tibia, as occurs with the avian homologues of these muscles (Hutchinson 2002, Carrano and Hutchinson 2002). The proximal portion of the right tibia of Staurikosaurus bears several striations that are similar to the scars observed in extant Caiman tibiae (Fig. 5E-H), which correspond to the insertion of FTI3 and FTE (posteromedially), and of FTI1, FTI2 and PIT (posterolaterally). Accordingly, the same condition is inferred for Staurikosaurus. Considering the proposed absence of PIT in Staurikosaurus (see below), the posterolateral striations seen on its tibia may correspond to the insertion of FTI1 (if present) and FTI2.

On its medial side, the proximal tibia of Staurikosaurus also bears a scar (partly lost due to fragmentation of the bone surface) distal to that of FTI3 and FTE (Fig. $5 \mathrm{G}$ ), which can be attributed to the M. gastrocnemius internus (that will not be treated here).

M. puboischiotibialis (PIT) - M. puboischiotibialis is present in basal reptiles, reduced in Crocodylia and absent in Aves (Romer 1923c, Hutchinson 2002, Carrano and Hutchinson 2002). In Crocodylia, there is only one branch of PIT originating on a scar located on the proximal tip of the obturator process $(o p)$ of the ischium (Carrano and Hutchinson 2002), ventral to the acetabulum (Romer 1923c). PIT inserts on the caudomedial surface of the proximal tibia, as a tendon shared with Mm. flexor tibiales interni 1 et 2 (Romer 1923c, Hutchinson 2002). The margin of the obturator process of the ischium of Staurikosaurus in not preserved, and it is impossible to determine the presence of PIT. Yet, Hutchinson (2002) points that the scar for PIT is absent in all basal archosaurs and that there is no evidence of one or more parts of PIT in Dinosauromorpha. Accordingly, it was probably also absent in Staurikosaurus.

M. flexor tibialis internus 1 (FTI1) - M. flexor tibialis internus 1 is absent in Aves and originates from the caudolateral surface of the distal ischium of crocodiles (Romer 1923c, Hutchinson 2002). Some theropods (e.g., Allosaurus, Piatnitzkysaurus, and Therizinosauroidea) and Herrerasaurus possess a structure (distal ischial tuberosity) on the caudolateral surface of the distal ischium that is topographically equivalent to FTI1 origin in Crocodylia (Hutchinson 2001a, 2002, Carrano and Hutchinson 2002). The distal part of the ischium of Staurikosaurus is not preserved, and the presence of the distal ischial tuberosity cannot be confirmed. Yet, it is present in Herrerasaurus and Saturnalia (Langer 2003), suggesting the presence of FTI1 in Staurikosaurus (Level II' inference).

M. flexor tibialis internus 2 (FTI2) - M. flexor tibialis internus 2, absent in Aves (Hutchinson 2002, Carrano and Hutchinson 2002), originates from the lateral surface of the postacetabular iliac process of crocodiles, ventral to the origin of FTE (Romer 1923c, Hutchinson 2002, Carrano and Hutchinson 2002). Langer (2003) indicated a division of muscle scars on the lateral surface of the postacetabular iliac process in Saturnalia and other dinosaurs (Herrerasaurus, Caseosaurus, basal ornithischias and 'prosauropods') that is topographically equivalent to the origins of FTI2 and FTE in Crocodylia. One of these marks is an extension of the dorsal iliac margin (origin of IT3) that corresponds to the origin area of FTE (Langer 2003). Posterior to this scar, on the caudal most part of the ilium, there is another scar probably associated with FTI2 (Langer 2003). These scars are not visible in Staurikosaurus, but a Level II' inference indicates the presence of FTI2 and FTE originating from its postacetabular iliac process, dorsal to the brevis shelf.

M. flexor tibialis internus 3 (FTI3) - M. flexor tibialis internus 3 of Crocodylia is equivalent to the inner part of FTI2 of basal Reptilia, in which the muscle is not divided (Hutchinson 2002). Its origin is located 
on the ischial tuberosity (it; Hutchinson 2001a, 2002), at the posterior margin of the ischium, proximal to the origin of ADD2 (Romer 1923c). It is homologous to the avian M. flexor cruris medialis (FCM), which originates from a similar (but distal) position, while the ischial tuberosity is absent (Hutchinson 2001a, 2002, Carrano and Hutchinson 2002). The ischium surface is not well preserved in Staurikosaurus, with fractures hampering the identification of muscle scars. However, both ischia bear a crest (Fig. 5 B-C) near the articular surface of the ilium that is slightly proximal in relation to the ischial tuberosity of other dinosaurs, but may be a homologous structure. Along with a depression lateral to the crest, these structures could correspond to the origin area of FTI3 as proposed by Langer (2003).

M. flexor tibialis internus 4 (FTI4) - This division of the flexor tibialis internus is only present in Crocodylia, and is equivalent to the superficial part of FTI2 of other Reptilia (Romer 1942, Hutchinson 2001a, 2002). FTI4 originates on the fascia around the caudoventral ilium and the caudodorsal ischium (Hutchinson 2002). Accordingly, its origin cannot be verified in Staurikosaurus because it is not correlated to any bone scar. Its presence is also equivocal, since it is absent in Aves.

M. flexor tibialis externus (FTE) - M. flexor tibialis externus (= flexor cruris lateralis pars pelvica, FCLP, in Aves) originates on the lateral surface of the ilium of crocodiles, posterior to $\mathrm{Mm}$. iliofibularis and iliofemoralis externus (Romer 1923c, Carrano and Hutchinson 2002). As already mentioned, the ilium of Staurikosaurus has no preserved muscle scar posterior to the origin of ILFB. The shape of the posterodorsal limit of ILFB in Staurikosaurus suggests the posterior extension of the dorsal border of the ilium (Fig. 4C), as seen in other taxa (e.g., in Saturnalia and Herrerasaurus, Langer [2003]). Accordingly, it is assumed that the origin of FTE in Staurikosaurus was posterior to ILFB and in continuity to that of IT3. FTI2 origin may be posterior to that of FTE, but their exact positions cannot be confirmed with current available material.

\section{ADDUCTORES FEMORES}

The muscle adductor femoris is divided in two parts in extant archosaurs: ADD1 and ADD2 in Crocodylia that are homologous to, respectively, M. pubosichiofemoralis pars medialis (PIFM) and pars lateralis (PIFL) in Aves (Romer 1923c, Hutchinson 2002). The two parts originate from the lateral surface of the ischium (ADD1 near the cranial border of the bone) and are separated, in Crocodylia, by the origin of PIFE3 (Romer 1923c). In Aves, the position of PIFL origin is anteroventral in relation to its crocodilian homologue, ADD2 (Hutchinson 2001a). This is probably related to the reduction of the obturator process, and the change of the origin of $\mathrm{M}$. ischiotrochantericus to the lateral surface of the ischium (Carrano and Hutchinson 2002).

According to Hutchinson (2001a), the ischial ridge (ir) is located cranioventrally to the origin of FTI3 and ventrally to ADD2. The bone surface of both ischia of Staurikosaurus is damaged, and no muscle scar can be safely identified. The ischial ridge is better seen in the left bone (Fig. 5C). On the right ischium, dorsal to the ischial ridge, in a well-preserved small area, a scar (Fig. 5B) topographically equivalent to the origin of ADD2 in Crocodylia may correspond to the origin of this muscle. The origin of ADD1 is probably located on the anterior margin of the obturator process, as in extant archosaurs, but this structure is not preserved in the holotype of Staurikosaurus.

The two ADD heads converge to a long and narrow insertion area, on the caudal surface of the distal femur (Romer 1923c), located between the linea intermuscularis caudalis and the linea aspera (adductor ridge, Hutchinson 2001b). These structures, as already mentioned, are partly preserved in the femora of Staurikosaurus and indicate the approximate position of ADD insertion. Unfortunately there is no distinct scar for either of the branches, as Carrano and Hutchinson (2002) observed in Tyrannosaurus.

\section{PUBOISCHIOFEMORALES EXTERNI}

Mm. Puboischiofemorales externi originate on the lateral surface of the pubo-ischiadic plate in basal archosaurs, and is divided in two pubic parts, PIFE1 and PIFE2. These are homologous to the avian Mm. obturatorius lateralis, OL, and obturatorius medialis, OM, respectively. Its ischiadic part, PIFE3, is absent in Aves (Hutchinson and Gatesy 2000). This plesiomorphic condition is retained in Crocodylia (Carrano and Hutchinson 
2002) and the modifications seen in Aves are attributed to the division of the pubo-ischiadic plate and loss of the obturator process (Hutchinson and Gatesy 2000).

The three heads of PIFE in Crocodylia shares an insertion tendon that attaches to the greater trochanter of the femur, as occurs with the avian homologues $\mathrm{OL}$ and OM (Hutchinson and Gatesy 2000, Hutchinson 2001b, Carrano and Hutchinson 2002). In Staurikosaurus, the greater trochanter is a S-shape crest located on the craniolateral region of the proximal region of the femur (Fig. 5D; Bittencourt and Kellner 2009). Galton (1977, 2000) previously identified this structure as the anterior trochanter (see Bittencourt and Kellner 2009, for a discussion).

M. puboischiofemoralis externus 1 (PIFE1) - In Staurikosaurus, PIFE1 originates on the anterior surface of the pubic apron ( $p a$; Fig. 5A), as seen in Crocodylia (Romer 1923c, Hutchinson 2002, Carrano and Hutchinson 2002). The apron corresponds to the dorsoventrally expanded surface of the pubic symphysis (Hutchinson 2001a). In Aves, which lack a pubic symphysis, PIFE1 originates from the proximal lateral surface of the pubis (Hutchinson 2002). Accordingly, the reconstrution proposed for Staurikosaurus corresponds to a Level II inference. Langer (2003) suggests the lateral surface of the distal part of the pubis of Herrerasaurus (as probably in Staurikosaurus) as equivalent to the anterior surface of the pubis of Saturnalia because it has a series of striations that continues from the anterior surface of the apron. These striations could indicate the origin of PIFE1 (Langer 2003). Extant archosaurs do not have any part of PIFE1 originating from the distal lateral surface of the pubis. As this supposition requires a Level III inference, it was not considered here.

Langer (2003) noted the laterally expanded lateral border of the pubis of Saturnalia, Herrerasaurus, and prosauropods, which gives the pubis a sinuous shape in anterior view. Novas (1993) erroneously (see Fig. 5A) indicated that Staurikosaurus retains the primitively straight dinosauromorph condition for the lateral border of the pubis. Langer (2003) proposed that the proximal margin of the lateral expansion of the pubis would indicate the passage of PIFE1 from the pubis in direction to the femur. In Staurikosaurus the expanded border is more dorsal if compared to the other basal Saurischia, and the origin of PIFE1 could be more dorsally expanded.

M. puboischiofemoralis externus 2 (PIFE2) - PIFE2 originates on the posterior surface of the pubic apron (Romer 1923c, Hutchinson 2002, Carrano and Hutchinson 2002). In Aves, the homologue OM has moved caudally to the pubo-ischiadic membrane (Hutchinson 2002). We consider (Level II inference) that Staurikosaurus has the same plesiomorphic condition of Crocodylia because the pubic apron is well developed.

M. puboischiofemoralis externus 3 (PIFE3) - PIFE3 originates from the lateral surface of the ischial obturator process, between the origin areas of ADD1 and ADD2 (Romer 1923c, Hutchinson 2002, Carrano and Hutchinson 2002). It is limited anterodorsally by the ischial ridge (Hutchinson 2002). In Aves, this muscle was lost together with the obturator process (Hutchinson 2001a, 2002). The obturator surface of the ischium of Staurikosaurus is not well preserved and no muscle scar is preserved. Accordingly, the origin of PIFE3 was tentatively reconstructed based on the position of the ischial ridge, PIFE3, ADD1, and ADD2 in Crocodylia.

\section{ISCHIOTROCHANTERICUS (ISTR)}

M. ischiotrochantericus (ISTR) of crocodiles originates on the medial surface of the caudal part of the ischium (Romer 1923c, Hutchinson 2001a, 2002, Carrano and Hutchinson 2002). In Aves, with the reduction of the ischial symphysis, the origin of the homologue M. ischiofemoralis (ISF) was displaced to the lateral surface of the ischium and to the ilio-ischiadic membrane (Hutchinson 2001a, 2002, Carrano and Hutchinson 2002).

In Aves, ISF is more cranial than in Crocodylia, in which ISTR is located on the caudal extremity of the ischium (Romer 1923c). But the distal part of the ischium in Aves corresponds to a caudoventral elongation of the distal part of the ischial symphysis (Hutchinson 2001a). Besides, the avian ISF is located near the origin of PIFM (= ADD1) and PIFL (= ADD2), as occurs in Crocodylia, and ISTR origin is medial to that of ADD2 (Carrano and Hutchinson 2002).

Accordingly, it is possible to infer that the origin of this muscle was displaced laterally in Aves, but not cranially or caudally. Sereno and Arcucci $(1993,1994)$ and 
Langer (2003) suggest that the dorsal surface of the dinosaur ischium was laterally displaced, so that the dorsal ridge of the ischium (dri), which separates the origins of ISTR and ADD2, is placed on the lateral surface of the ischium (Langer 2003). In Staurikosaurus, the ridge that separates ISTR from ADD2 is visible and helps to define the approximate position of ISTR origin, which is near and dorsal to the scar that supposedly indicates the origin of ADD2.

In Crocodylia, ISTR inserts on a scar on the caudolateral surface of the proximal femur (Romer 1923c, Hutchinson 2002), in a position almost equal to that seen in Aves (Hutchinson 2002). Dinosauromorphs have a sigmoid structure (trochanteric shelf) that corresponds to the insertion of IFE. A groove proximal to the trochanteric shelf corresponds to the insertion of ISTR (Hutchinson 2001b, 2002, Carrano and Hutchinson 2002). The trochanteric shelf of Staurikosaurus is reduced (Bittencourt and Kellner 2009), but the groove where ISTR is inserted is present and clearly seen on the left femur (Fig. 5D).

\section{CAUDOFEMORALES}

M. caudofemoralis brevis (CFB) - M. caudofemoralis brevis of crocodiles (= caudofemoralis pars pelvica, CFP, in Aves) originates on a shallow fossa on the medioventral surface of the ilium, from the posterior sacral ribs and the first caudal vertebra (Romer 1923c, Carrano and Hutchinson 2002). In Aves, CFP originates only from the caudolateral surface of the ilium (Hutchinson 2002). Changes in the origin of CFB/CFP are apparently related to modifications of the medial and lateral regions of the postacetabular ilium, which include the transversal widening and deepening of both the iliac blade and the medial shelf, forming the brevis shelf $(b s)$ and the brevis fossa of Dinosauria (Novas 1996, Hutchinson 2001a, 2002). Accordingly, CFB of dinosaurs would have its origin from the brevis fossa, which is reduced in taxa proximally related to Aves (Hutchinson 2001a, 2002).

According to Novas (1992), Herrerasauridae retains the plesiomorphic condition of basal Ornithodira (e.g., Lagerpeton and Lagosuchus), in which the brevis fossa is absent so that this structure would be novel for Ornithischia + Saurischia. In following works, Novas
(1993, 1996) considered herrerasaurids as basal theropods and suggested that a groove on the lateral surface of the posterior part of the ilium of Herrerasaurus represents a reduced brevis fossa. Hutchinson (2001a) also treats Herrerasauridae as basal Theropoda and suggests that the most parsimonious condition would be the reduction of the brevis fossa in this group. Even if we consider Herrerasauridae as basal Saurischia (Yates 2003, Langer 2004, Leal et al. 2004), the reduction hypothesis is more parsimonious since ornithischians also have a well-developed fossa (Novas 1992, 1996).

The reduction of the brevis fossa appears to be more pronounced in Staurikosaurus than in Herrerasaurus, because just a shallow depression on the lateral postacetabular surface of the ilium is present. This depression is dorsally delimited by an elongated elevation that starts at the dorsoposterior margin of the supra-acetabular crest, finishing on the posterior margin of the ilium. This structure is interpreted as homologue to both the ridge that bounds the groove of the posterior ilium of Herrerasaurus, and the brevis shelf. Accordingly, the surface ventral to this shelf (posteroventral margin of the ilium) corresponds to the medial blade of the ilium, which bounds the brevis fossa medially (medial blade of the brevis fossa, mbbf; Fig. 4C) in other Dinosauria. Therefore, the lateral surface of this blade would represent the origin of CFB in Staurikosaurus. Despite the reduction of the brevis fossa, Staurikosaurus possesses a marked dorsoventral expansion of the posterior part of the posteroventral margin of the ilium (Fig. 4C), which does not occur in Herrerasaurus. In both taxa, the medial blade (posteroventral margin of the ilium) corresponds to $29 \%$ of the length of the ilium, but the posterior part in Herrerasaurus is not dorsoventrally expanded, suggesting that the posterior part of CFB was enlarged in Staurikosaurus.

CFB inserts on the posterolateral surface of the femur, between the fourth trochanter and the linea intermuscularis caudalis (Hutchinson 2001a, b, 2002, Carrano and Hutchinson 2002) in a position slightly proximal and lateral to the insertion of M. caudofemoralis longus (Romer 1923c). In Aves, the fourth trochanter is reduced to a scar and the insertion of CFP is adjacent to this scar (Hutchinson 2002). The left femur of Staurikosaurus has well-preserved fourth trochanter and 
linea intermuscularis caudalis, but no muscle scars are observed. Accordingly, the inferred position of CFB insertion is approximate.

M. caudofemoralis longus (CFL) - M. caudofemoralis longus (= caudofemoralis pars caudalis, CFC, in Aves) originates on the centra and ventral surfaces of the caudal vertebra transverse processes (Romer 1923c, Gatesy 1990, Hutchinson 2001b), approximately from the third to the fifteenth element (Romer 1923c, Gatesy 1990). In Aves, CFC was reduced along with the reduction of the tail and the evolution of the pygostyle, and its origin is restricted to this structure (Gatesy 1990, Hutchinson 2002). The presence of transverse processes would be an indication of the minimal extension of the origin of CFL in the tail of archosaurs, as are specializations of the vertebrae and chevrons (Gatesy 1990). In Theropoda, the tail has a transition point where the caudal vertebrae lose the transverse processes (Russell 1972), so that the origin of the CFL is restricted to the area anterior to this point. The transition is also marked by the elongation of the prezygapophyses and dorsoventral compression of the chevrons on the vertebrae posterior to the point (Gauthier 1986, Gatesy 1990).

The holotype of Staurikosaurus does not have the complete caudal series preserved: there are six proximal vertebrae; a block containing six articulated vertebrae from the middle part of the tail; two blocks with two vertebrae each, also from the middle of the tail; and the last 19 caudal vertebrae (Bittencourt and Kellner 2009). Vertebrae from one of the median blocks with two vertebrae bear transverse processes. But the 19 terminal vertebrae lack these structures and have elongated prezygapophyses (Gauthier 1986, Bittencourt and Kellner 2009). Based on regression equations obtained from data collected from the preserved caudal vertebrae (height and length of the centrum), and considering that Staurikosaurus had the same number of caudal vertebrae of Herrerasaurus (i.e., 47 vertebrae), it was possible to estimate the position of the middle blocks of vertebrae. This method also allowed estimating the length of the non-preserved vertebrae and indicated that the block containing the two vertebrae with transverse processes corresponds to the $24^{\text {th }}$ and $25^{\text {th }}$ caudal elements (Grillo and Azevedo 2011). Accordingly, at least
25 caudal vertebrae of Staurikosaurus have transverse processes, and this is the minimal extension of CFL origin (Grillo and Azevedo 2011).

CFL of crocodiles inserts on the medial surface of the fourth trochanter, on an associated depression (Romer 1923c, Gatesy 1990, Hutchinson 2001b, 2002). In Aves, the reduction of CFC was accompanied by the reduction of the fourth trochanter to a roughed area (Gatesy 1990, Hutchinson 2001b, 2002). Staurikosaurus possesses a well-developed crest-shaped fourth trochanter (Colbert 1970, Galton 1977, 2000, Bittencourt and Kellner 2009) that indicates that the CFL was a large and powerful muscle. This condition is congruent with the expanded area of origin of this muscle in the tail.

In extant crocodiles the CFL has a secondary tendon that extends from the distal part of CFL to the caudal region of the knee (Romer 1923c, Hutchinson 2001b, 2002), contributing to the origin of the M. gastrocnemius lateralis (Hutchinson 2002). In Theropoda, the fourth trochanter is pendant and has a process ventrally directed that could be an indication of the presence of this secondary tendon (Hutchinson 2002, Carrano and Hutchinson 2002). Staurikosaurus has a pendant fourth trochanter, although its margin is damaged and the ventral process cannot be observed, so that the secondary tendon was probably present (Level II' inference).

\section{DISCUSSION}

Reconstructions of the pelvic musculature of saurischian dinosaurs have been attempted for more than a century (Romer 1923b, c), but recent works (e.g. Hutchinson 2001a, b, 2002) clarified several aspects of the evolution of the hind limb muscles in archosaurs. Some studies (e.g. Coombs 1979, Dilkes 2000, Carrano and Hutchinson 2002, Langer 2003) did not focus on higher level taxa, but on particular species. This approach may reveal exclusive adaptations, contributing to understand the different locomotion adaptations of each species.

The muscle reconstruction of Staurikosaurus allowed the identification of both modifications that differentiate this taxon from other closely related species, and of a series of osteological structures not observed by other authors that studied this specimen. Differently from other works, the reconstruction of the hind limb musculature of Staurikosaurus was based on a single 
specimen, which has several problems of preservation that hampered the observation of muscle scars. However, the comparison with other proximally related taxa and the use of bones from both sides of the body, associated to the EPB methodology, allowed to construct a map of origin and insertion for the majority of the hind limb muscles. The result is consistent to muscle arrangement in extant archosaurs and other extinct dinosaurs that have already been studied (see Carrano and Hutchinson 2002, Langer 2003).

Some muscle associated structures were described for the first time for Staurikosaurus, complimenting previous descriptions and studies about this taxon (Colbert 1970, Galton 1977, 2000, Bittencourt and Kellner 2009): the pubic tubercle (associated to AMB origin), the lineae intermusculares on the femur (associated to FMTE, FMTI, ADD1-2 and CFB), the two concavities on the lateral surface of the ilium (associated to ITC, IFE and ILFB origin), the concavities on the posterior dorsal vertebrae (associated to PIFI2 origin) and the fossa on the ventral margin of the cranial iliac process (probably associated to PIFI1 origin). The pubic tubercle has been figured as absent in Staurikosaurus (e.g., Colbert 1970, Galton 1977, Novas 1993), and a recent revision (Bittencourt and Kellner 2009) did not recognize this tubercle, perhaps as a result of taphonomic damage. All these studies were based on the right pubis, but the pubic tubercle is preserved only on the left pubis (Fig. 5A).

The concavities on the lateral surface of the ilium described here are different from those mentioned by Bittencourt and Kellner (2009). These authors indicate that the ilium of Staurikosaurus has two concavities on the lateral surface, the caudal one being interpreted as a reduced brevis fossa. The cranial concavity indicated by Bittencourt and Kellner (2009) was interpreted here as comprising two concavities associated to the origins of IFE, ITC, and ILFB (concavities 1 and 2, Fig. 4A-C).

The muscle reconstruction of Staurikosaurus may be compared to that presented by Langer (2003) for another basal Saurischian, Saturnalia tupiniquim. Langer (2003) indicated that the hind limb and pelvic anatomy of Saturnalia, and hence muscle arrangement and function, would be representative of a general construction shared by basal dinosauriforms such as Marasuchus and Pseudolagosuchus, and basal dinosaurs, including Her- rerasaurus, Staurikosaurus, Guaibasaurus, and basal sauropodomorphs. Most of the results presented are very similar to those of Langer (2003). Differences are mainly conceptual, rather than anatomical.

As proposed by Langer (2003), we consider that the tenuous convexity that separates the two main concavities on the lateral surface of the ilium indicates the anterior limit of ILFB origin. However, Langer (2003) proposed that the anterior concavity corresponds solely to the origin of ITC, so that the origin of IFE would be located on the surface immediately caudal to the supraacetabular crest or close to the dorsal margin of the ilium, over the dorsal extremity of the convexity that separates the two main lateral iliac concavities (Fig. 3L). The first hypothesis is congruent with the arrangement seen in Crocodylia, in which the origin of IF borders the dorsoposterior margin of the acetabulum. In this context, IFE would have originated as a posteroventral division of IF. This is not congruent with the origin of IFE in Aves, which is located on the dorsal margin of the ilium on the processus supra-trochantericus (pst; Fig. 3O; Hutchinson 2001a). This indicates that IFE represents a dorsoposterior separation of IF, which is congruent with the second hypothesis of Langer (2003). If this last hypothesis is accepted, it is also necessary to infer that IF splited into a reduced IFE and a large ITC. Yet, osteological evidence suggests that ITC was initially of similar size to IFE, enlarging only along theropod evolution until it was reduced again in Aves, and restricted to the dorsal margin of the ilium. This is supported by the enlargement of the anterior trochanter and cranial iliac process in basal theropods, and by the later reduction of the former in taxa closely related to Aves (Hutchinson and Gatesy 2000, Hutchinson 2001b). Another indication that IFE and ITC had similar sizes in non-maniraptoran theropods is the presence of a dorsoventrally directed convexity on the lateral surface of the anterior iliac process, which divides the anterior concavity of the ilium, separating the origins of ITC and IFE in Tyrannosaurus (Carrano and Hutchinson 2002), as well as in the ornithomimosaur Sinornithomimus dongi. In this context, the most parsimonious scenario for the evolution of these muscles is the division of IF in two muscles of similar size in basal dinosaurs whose origins shared the anterior concavity of the ilium. 
Another difference between the proposition of Langer (2003) for Saturnalia and the one presented here for Staurikosaurus is related to AMB. Langer (2003) proposed that this muscle, as in Crocodylia, would have two heads originating from the pubic tubercle and from the dorsal margin of the pubis. On the contrary, we consider that the AMB of dinosaurs, as in Aves, would have just one head, originating from the pubic tubercle. According to Carrano and Hutchinson (2002), the presence of two heads in Crocodylia represents an apomorphy of this clade because both Aves and Lepidosauria have just one AMB head (Romer 1922, 1923c).

Other differences relative to the reconstruction presented by Langer (2003) are related to insufficient information retrieved from the holotype of Staurikosaurus. The smooth division on the femur of Saturnalia that could indicate the separation of FMTI in two parts (FMTM and FMTIM) was not preserved or is absent in Staurikosaurus. The phylogenetic positioning of Herrerasauridae is still uncertain. Some works (e.g. Yates 2003, Leal et al. 2004, Bittencourt and Kellner 2009) place Herrerasauridae basal to Eusaurischia, but others (e.g., Novas 1993, Sereno 1997, Sereno and Novas 1992, Benton 1999) suggest a closer relation to Theropoda. Accordingly, the presence of an initial division of FMTI in Saturnalia does not bring additional evidences for its division in Herrerasauridae until more stable phylogenetic hypotheses are obtained.

We restricted the origin of PIFE3 to the obturator process, as in Crocodylia, because the obturator process is not completely preserved and no muscle scar could be observed. Yet, Langer (2003) observed striations on the ventrolateral surface of the ischium of Saturnalia, which were associated to PIFE3. This could also be the case for Staurikosaurus, but new material is necessary to confirm this hypothesis. Besides, Langer (2003) reconstructed ISTR as originating from the entire mediodorsal surface of the ischium, but the distal part of that bone forms an elongated symphysis (Hutchinson 2001a). Moreover, in Crocodylia, ISTR origin is restricted to the obturator process and does not extend into the symphysis. In Aves, the homologue ISF is also restricted to the proximal portion of the ischium, so that there is no support from extant taxa for a distal extension of this muscle in dinosaurs.

Finally, Langer (2003) attributed scars on the pu- bic peduncle to the origin of PIFI1 or the dorsal part of AMB. In the prosauropod Sellosaurus gracilis there is a depression on the ventral margin of the cranial iliac process that extends to the pubic peduncle (Fig. 4E). This is equivalent to the fossa observed on the cranial process of the ilium of Staurikosaurus (Fig. 4C-D) and Caseosaurus (Fig. 4F-G), which are in the same position of the preacetabular fossa of Avetheropoda (Fig. 4H-I). The preacetabular fossa of Avetheropoda was attributed to the origin of PIFI1, since it is the condition of the avian homologue IFI (Hutchinson 2002). Accordingly, it is possible to infer that early on dinosaur evolution PIFI1 changed its origin from the medial surface of the ilium, as is the case for Crocodylia, to the ventral margin of the cranial iliac process and the dorsal part of the pubic peduncle of the ilium. Later on Theropod evolution, the incorporation of dorsal vertebrae to the sacrum led to the rearrangement of the first medial iliac ridge and to the development of the preacetabular fossa as defined for Avetheropoda by Hutchinson (2001a).

In conclusion, disregarding the differences pointed above, it is possible to confirm that basal dinosaurs shared a similar muscle arrangement as proposed by Langer (2003).

In the following paragraphs, this arrangement is compared with that of extant Crocodylia and Aves and to the reconstruction presented by Carrano and Hutchinson (2002) for Tyrannosaurus, in the intent to discuss some aspects of hind limb muscle evolution in Saurischia.

Relative to Crocodylia, Staurikosaurus differs in various aspects: (1) the iliac surface for muscle origins is proportionally larger, especially on the anterior portion of the bone, due to the expansion of the cranial iliac process; (2) the origin of ILFB is also enlarged, occupying a large concavity on the lateral surface of the ilium; (3) IF is divided; (4) AMB has just one head; and (5) PIFI1 apparently moved from the medial surface of the ilium to a fossa on the ventral margin of the cranial iliac process and dorsal part of the pubic peduncle. Other muscles in Staurikosaurus, such as CFB, CFL, PIFE1-2, and PIFI2, have origin and insertion areas in positions equivalent to Crocodylia.

All the changes listed above for Staurikosaurus were also observed in Tyrannosaurus (Carrano and Hutchinson 2002). The most notable difference between 
these two taxa is the existence of a true preacetabular fossa on the ventral margin of the cranial iliac process of Tyrannosaurus, but Staurikosaurus also bears other dissimilarities including: (1) reduced anterior trochanter; (2) the femoral head in its plesiomorphic orientation, rotated $45^{\circ}$ posteriorly; (3) a more proximal insertion of FTI3 and FTE and origin of ADD2 and FTI3; (4) more posterior origin of IFE; (5) reduced brevis fossa; and (6) a CFB origin extending to the posterior margin of the ilium and with its posterior part dorsoventrally expanded. The arrangement of other muscles are similar in both taxa or is uncertain in Staurikosaurus (e.g., origins of ADD1 and PIFE3) or in Tyrannosaurus (presence or absence of FTI1 and FTI2). Other differences are related to the proportionately larger bone surfaces of Tyrannosaurus due to the expansion of the cranial and caudal processes of the ilium.

Differences in muscle position observed between Staurikosaurus and Tyrannosaurus are related to changes in muscle function, as is the case of ADD2, FTI3, and FTE, which have their origins in a more distal position. This makes ADD2 to change its primary function from adductor to extensor and increases the moment arm of FTI3 and FTE (Carrano and Hutchinson 2002).

Based on the comparison between Staurikosaurus and Tyrannosaurus, it is possible to infer that the main features of the avian musculature present in Tyrannosaurus were also present early on saurischian evolution, e.g., a divided IF (Hutchinson 2001b) and the origin of PIFI1 from the ventral surface of the cranial process of the ilium. Modifications not present early on the evolution of Saurischia, but present in Tyrannosaurus, include: (1) the expanded anterior trochanter (Hutchinson and Gatesy 2000); (2) the expansion of the cranial and caudal iliac processes (Carrano 2000), which is less evident in basal dinosaurs; and (3) the rotation of the femoral head, the lateral surface of which moved to a more anterior position (Carrano 2000, Hutchinson 2001b).

The reconstruction of pelvic and hind limb musculature of Staurikosaurus also revealed a specific adaptation unknown to other taxa: the posterior part of the origin of CFB (the medial blade of the brevis fossa) is dorsoventrally expanded (Fig. 4C), which probably allocated a larger posterior part of CFB. Compared to
Herrerasaurus, this expansion characterizes a volume increase of CFB, since the length of the medial blade of the brevis fossa corresponds to $29 \%$ of the total length of the ilium in both taxa.

\section{ACKNOWLEDGMENTS}

The Museum of Comparative Zoology is thanked for the loan of the $S$. pricei holotype to Alexander Kellner, Museu Nacional/UFRJ. Jonathas de Souza Bittencourt is thanked for providing the photographs of the $S$. pricei holotype and Riccardo Mugnai is thanked for preparing the casts of the holotype. This research is part of the MSc thesis of one of the authors (ONG) at the Museu Nacional of Universidade Federal do Rio de Janeiro, funded by a fellowship of the Conselho Nacional de Desenvolvimento Científico e Tecnológico (CNPq) and of the Fundação Carlos Chagas Filho de Amparo à Pesquisa do Estado do Rio de Janeiro (FAPERJ). The thesis was examined by the doctors Max Langer, Alexander Kellner and Oscar Rocha-Barbosa, who are thanked for providing useful comments that greatly improved the final version of this paper.

\section{RESUMO}

$\mathrm{O}$ estudo da musculatura pélvica e do membro posterior em dinossauros basais é importante para entender a evolução inicial do bipedalismo em dinossauros Saurischia. Empregando uma metodologia que tem como base dados obtidos a partir de táxons viventes e extintos posicionados em um contexto filogenético, foi possível fazer inferências bem suportadas relativas à maior parte dos músculos do membro posterior do dinossauro Saurischia basal Staurikosaurus pricei Colbert, 1970 (Formação Santa Maria, Triássico Superior do Rio Grande do Sul, Brasil). Duas grandes concavidades na superfície lateral do ílio correspondem à origem dos músculos iliotrochantericus caudalis e iliofemoralis externus (compartilhando a concavidade anterior) e para o músculo iliofibularis (na concavidade posterior). O músculo ambiens apresenta apenas um ramo que se origina no tubérculo púbico. A origem provável do músculo puboischiofemoralis internus 1 está localizada numa fossa na margem ventral do processo pré-acetabular do ílio, representando um estágio anterior à formação da verdadeira fossa préacetabular. Os músculos caudofemorales longus et brevis são bem desenvolvidos e Staurikosaurus é único por apresentar a superfície de origem do músculo caudofemoralis brevis projetada e expandida posteriormente. 
Palavras-chave: “extant phylogenetic bracket", locomoção, reconstrução muscular, Saurischia, Staurikosaurus pricei.

\section{REFERENCES}

ALEXANDER RMCN. 1976. Estimates of speeds of dinosaurs. Nature 261: 129-130.

AlEXANDER RMCN. 2004. Bipedal animals, and their differences from humans. J Anat 204: 321-330.

BARSBOLd R AND OSMÓlska H. 1990. Ornithomimosauria. In: WeIshampel DB ET AL. (Eds), The Dinosauria, Berkeley: University of California Press, p. 225-244.

BENTON MJ. 1999. Scleromochlus taylori and the origin of dinosaurs and pterosaurs. Philos T R Soc B 354: 14231446.

Benton MJ AND Clark JM. 1988. Archosaur phylogeny and the relationships of the Crocodylia. In: BENTON MJ (Ed), The phylogeny and classification of the Tetrapods, Vol. 1: Amphibians, Reptiles, Birds, Systematics Association Special 35 A: 295-338.

Bittencourt JS And Kellner AWA. 2009. The anatomy and phylogenetic position of the Triassic dinosaur Staurikosaurus pricei Colbert, 1970. Zootaxa 2079: 1-56.

Bonaparte JF. 1996. Dinosaurios de America del Sur. Buenos Aires: Museo Argentino de Ciencias Naturales "Bernardino Rivadavia", 174 p.

Bonaparte JF, Ferigolo J And Ribeiro AM. 1999. A new early Late Triassic saurischian dinosaur from Rio Grande do Sul State, Brazil. In: TomIDA Y ET AL. (Eds), Proceedings of the Second Gondwanaland Dinosaur Symposium, Tokyo: National Science Museum Monographs 15: 89-109.

Bonaparte JF, Novas FE And Coria RA. 1990. Carnotaurus sastrei Bonaparte, the horned, lightly built carnosaur from the Middle Cretaceous of Patagonia. Contrib. Sci Nat Hist Mus Los Angeles Co 416: 1-42.

BRINKMAN DB AND SUES H-D. 1987. A staurikosaurid dinosaur from the Upper Triassic Ischigualasto Formation of Argentina and the relationships of the Staurikosauridae. Palaeontology 30: 493-503.

BRYANT HN AND RUSSELL AP. 1992. The role of phylogenetic analysis in the inference of unpreserved attributes of extinct taxa. Philos T R Soc B 337: 405-418.

Calvo JO, Porfiri JD And Kellner AWA. 2004. On a new maniraptoran dinosaur (Theropoda) from the Upper Cretaceous of Neuquén, Patagonia, Argentina. Arq Mus Nacional 62: 549-566.
CARrano MT. 1999. What, if anything, is a cursor? Categories versus continua for determining locomotor habit in mammals and dinosaurs. J Zool (London) 247: 29-42.

Carrano MT. 2000. Homoplasy and the evolution of dinosaur locomotion. Paleobiology 26: 489-512.

CARRANO MT. 2001. Implications of limb bone scaling, curvature and eccentricity in mammals and non-avian dinosaurs. J Zool (London) 254: 41-55.

Carrano MT And Hutchinson JR. 2002. Pelvic and hindlimb musculature of Tyrannosaurus rex (Dinosauria: Theropoda). J Morphol 253: 207-228.

CARrano MT, SAMPSON SD AND Forster CA. 2002. The osteology of Masiakasaurus knopfleri, a small abelisauroid (Dinosauria: Theropoda) from the Late Cretaceous of Madagascar. J Vert Paleontol 22: 510-534.

CARRIER DR, WALter RM AND LEE DV. 2001. Influence of rotational inertia on turning performance of theropod dinosaurs: clues from humans with increased rotational inertia. J Exp Biol 204: 3917-3926.

Clarke JA. 2004. Morphology, phylogenetic taxonomy, and systematics of Ichthyornis and Apatornis (Avialae: Ornithurae). Bull Am Mus Nat Hist 286: 1-179.

Colbert EH. 1964. Relationships of the Saurischian Dinosaurs. Am Mus Novit 2181: 1-24.

Colbert EH. 1970. A saurischian dinosaur from the Triassic of Brazil. Am Mus Novit 2405: 1-60.

Colbert EH. 1989. The Triassic dinosaur Coelophysis. Bull Mus N Arizona 57: 1-160.

CoOMBS JR WP. 1979. Osteology and myology of the hindlimb in the Ankylosauria (Reptilia, Ornithischia). J Paleontol 53: 666-684.

COOMBS JR WP. 1980. Swimming ability of carnivorous dinosaurs. Science 207: 1198-1200.

CORIA RA AND CURRIE PJ. 2006. A new carcharodontosaurid (Dinosauria, Theropoda) from the Upper Cretaceous of Argentina. Geodiversitas 28: 71-118.

CURRIE PJ. 2000. Theropods from the Cretaceous of Mongolia. In: BENTON MJ, SHISHKIN MA, UNWIN DM AND KUROCHKIN EN (Eds), The age of dinosaurs in Russia and Mongolia. Cambridge: Cambridge University Press, p. 434-455.

Currie PJ AND Chen P-J. 2001. Anatomy of Sinosauropteryx prima from Liaoning, northeastern China. Can J Earth Sci 38: 1705-1727.

Day JS, Norman DB, UpChurch P AND POWEll HP. 2002. Dinosaur locomotion from a new trackway. Nature 415: 494-495. 
DiLKES DW. 2000. Appendicular myology of the hadrosaurian dinosaur Maiasaura peeblesorum from the Late Cretaceous (Campanian) of Montana. Trans R Soc Edinb, Earth Sci 90: 87-125.

FARLOW JO. 1981. Estimates of dinosaur speeds from a new trackway site in Texas. Nature 294: 747-748.

GADow H. 1880. Zur vergleichenden Anatomie der Muskulatur des Beckens und der hinteren Gliedmasse der Ratiten. Jena: G. Fischer.

GALton PM. 1977. On Staurikosaurus pricei, an early saurischian dinosaur from The Triassic of Brazil, with notes on the Herrerasauridae and Poposauridae. Paläntol Z 51: 234-245.

GALTON PM. 1984. An early prosauropod dinosaur from the upper Triassic of Nordwürttemberg, West Germany. Stuttgarter Beitr Naturkd, ser B, 106: 1-25.

Galton PM. 2000. Are Spondylosoma and Staurikosaurus (Santa Maria Formation, Middle-Upper Triassic, Brazil) the oldest saurischian dinosaurs? Paläntol Z 74: 393-423.

GATESY SM. 1990. Caudofemoral musculature and the evolution of theropod locomotion. Paleobiology 16: 170186.

GATESY SM. 1999. Guinea fowl limb function. I: Cineradiographic analysis and speed effects. J Morphol 240: $115-125$.

GATESy SM AND BIEWENER AA. 1991. bipedal locomotion: effects of speed, size and limb posture in birds and humans. j zool (london) 224: 127-147.

Gatesy SM, Middleton KM, Jenkins JR FA AND ShUBIN NH. 1999. Three-dimensional preservation of foot movements in Triassic theropod dinosaurs. Nature 399: 141-144.

GAUTHIER J. 1986. Saurischian monophyly and the origin of birds. In: PADIAN K (Ed), The origin of birds and the evolution of flight, Mem California Acad Sci 8: 1-55.

GOODRICH ES. 1958. Studies on the structure and development of vertebrates. New York: Dover Publications 1: 485.

Gregory WK And CAMP CL. 1918. Studies in comparative myology and osteology. III. Bull Am Mus Nat Hist 38: 447-563.

Grillo ON AND AZEVEDo SAK. 2011. Recovering missing data: estimating position and size of caudal vertebrae in Staurikosaurus pricei Colbert, 1970. An Acad Bras Cienc 83: 61-71.

HENDERSON DM. 1999. Estimating the masses and centers of mass of extinct animals by 3-D mathematical slicing. Paleobiology 25: 88-106.

HOLTZ JR TR. 1998. A new phylogeny of the carnivorous dinosaurs. Gaia 15: 5-61.

HuAng SH, Norell MA And KeqIN G. 2004. A large Compsognathid from the Early Cretaceous Yixian formation of China. J Syst Palaeont 2: 13-30.

Huene F VON. 1908. Die Dinosaurier der Europaischen Triasformation, mit Berucksichtigung der Aussereuropaischen vorkommnisse: Geologische und Palaeontologische Abhandlungne, Supp band 1: 1-419.

Hunt AP, Lucas SG, Heckert AB, Sullivan RM AND LOCKLEY MG. 1998. Late Triassic dinosaurs from the western United States. Geobios 31: 511-531.

HUTCHINSON JR. 2001a. The evolution of pelvic osteology and soft tissues on the line to extant birds (Neornithes). Zool J Linn Soc 131: 123-168.

HUTCHINSON JR. 2001b. The evolution of femoral osteology and soft tissues on the line to extant birds (Neornithes). Zool J Linn Soc 131: 169-197.

Hutchinson JR. 2002. The evolution of hindlimb tendons and muscles on the line to crown-group birds. Comp Biochem Physiol A 133: 1051-1086.

HutCHINSON JR. 2004a. Biomechanical modeling and sensitivity analysis of bipedal running ability. II. Extinct taxa. J Morphol 262: 441-461.

HUTCHINSON JR. 2004b. Biomechanical modeling and sensitivity analysis of bipedal running ability. I. Extant taxa. J Morphol 262: 421-440.

Hutchinson JR, Anderson FC, Blemker SS AND DELP SL. 2005. Analysis of hindlimb muscle moment arms in Tyrannosaurus rex using a three-dimensional musculoskeletal computer model: implications for stance, gait, and speed. Paleobiology 31: 676-701.

HUtChinson JR AND GARCIA M. 2002. Tyrannosaurus was not a fast runner. Nature 415: 1018-1021.

Hutchinson JR And Gatesy SM. 2000. Adductors, abductors, and the evolution of archosaur locomotion. Paleobiology 26: 734-751.

HUtChinson JR AND GATESY SM. 2006. Beyond the bones. Nature 440: 292-294.

ISHIGAKI S. 1989. Footprints of swimming sauropods from Morocco. In: GilletTe DD AND LocKLEY MG (Eds), Dinosaur Tracks and Traces, Cambridge: Cambridge University Press, p. 83-86.

JASINOSKi SC, Russell AP AND CURRIE PJ. 2006. An integrative phylogenetic and extrapolatory approach to 
the reconstruction of dromaeosaur (Theropoda : Eumaniraptora) shoulder musculature. Zool J Linn Soc 146: 301344.

Ji Q, NoRell MA, MAKOVICKY PJ, GAO K-Q, Ji SA AND YUAN C. 2003. An early ostrich dinosaur and implications for ornithomimosaur phylogeny. Am Mus Novit 3420: 1-19.

Jones TD, FARlow JO, Ruben JA, Henderson DM AND HilleniUs WJ. 2000. Cursoriality in bipedal archosaurs. Nature 406: 716-718.

KoBAYASHI Y AND LÜ J-C. 2003. A new ornithomimid dinosaur with gregarious habits from the Late Cretaceous of China. Acta Palaeont Polonica 48: 235-259.

LANGER MC. 2003. The pelvic and hind limb anatomy of the stem-sauropodomorph Saturnalia tupiniquim (Late Triassic, Brazil). PaleoBios 23: 1-40.

LANGER MC. 2004. Basal Saurischia. In: WeISHAMPEL DB ET AL. (Eds), The Dinosauria, $2^{\text {nd }}$ ed., Berkeley: University of California Press, p. 25-46.

LeAl LA, AzEvedo SAK, Kellner AWA AND DA RosA AAS. 2004. A new early dinosaur (Sauropodomorpha) from the Caturrita Formation (Late Triassic), Paraná Basin, Brazil. Zootaxa 690: 1-24.

Lloyd GT, Davis Ke, Pisani D, TARver JE, Ruta M, SAKAmoto M, Hone DWE, Jennings R And BenTON MJ. 2008. Dinosaurs and the cretaceous terrestrial revolution. Proc R Soc B 275: 2483-2490.

Lockley MG AND GiLlette DD. 1989. Dinosaur tracks and traces: an overview. In: GILLETTE DD AND LOCKLEY MG (Eds), Dinosaur Tracks and Traces, Cambridge: Cambridge University Press, p. 3-10.

LONG RA AND MURRY PA. 1995. Late Triassic (Carnian and Norian) Tetrapods from the Southwestern United States. New Mexico Mus Nat Hist Sci Bull 4: 1-254.

Madsen JR JH. 1993. Allosaurus fragilis: A revised osteology, $2^{\text {nd }}$ ed, Utah Geol Survey Bull 109: 1-163.

MAKoviCKY PJ AND SuEs H-D. 1998. Anatomy and phylogenetic relationships of the theropod dinosaur Microvenator celer from the Lower Cretaceous of Montana. Am Mus Novit 3240: 1-27.

MCGOWAN C. 1999. A practical guide to vertebrate mechanics. Cambridge: Cambridge University Press, 301 p.

Molnar RE, Kurzanov SM ANd Zhiming D. 1990. Carnosauria. In: Weishampel DB ET AL. (Eds), The Dinosauria, Berkeley: University of California Press, p. 169-209.
NAish D, Martill DM And Frey E. 2004. Ecology, systematics and biogeographical relationships of dinosaurs, including a new theropod, from the Santana Formation (?Albian, Early Cretaceous) of Brazil. Hist Biol 16: 5770 .

Norell MA, Clark JM ANd Makovicky PJ. 2001. Phylogenetic relationships among coelurosaurian theropods. In: GAUThIER JA AND GAll LF (Eds), New Perspectives on the Origin and Early Evolution of Birds, New Haven: Yale University Press, p. 49-67.

NoREll MA AND MAKOVICKY PJ. 1999. Important features of the dromaeosaurid skeleton II: Information from newly collected specimens of Velociraptor mongoliensis. Am Mus Novit 3282: 1-45.

Norman DB. 1990. Problematic Theropoda: "Coelurosaurs". In: Weishampel DB ET AL. (Eds), The Dinosauria, Berkeley: University of California Press, p. 280-305.

Novas FE. 1992. Phylogenetic relationships of the basal dinosaurs, the Herrerasauridae. Paleontology 35: 51-62.

NOVAS FE. 1993. New information on the systematics and postcranial skeleton of Herrerasaurus ischigualastensis (Theropoda: Herrerasauridae) from the Ischigualasto Formation (Upper Triassic) of Argentina. J Vert Paleontol 13: 400-423.

NovAs FE. 1996. Dinosaur monophyly. J Vert Paleontol 16: $723-741$.

OsBorn HF. 1904. Manus, sacrum, and caudals of sauropoda. Bull Am Mus Nat Hist 20: 181-190.

OsBORN HF. 1905. Tyrannosaurus and other Cretaceous carnivorous dinosaurs. Bull Am Mus Nat Hist 21: 259-265.

OsBorn HF. 1916. Skeletal adaptations of Ornitholestes, Struthiomimus, Tyrannosaurus. Bull Am Mus Nat Hist 35: 733-771.

Ostrom JH. 1969. Osteology of Deinonychus antirrhopus, an unusual theropod from the Lower Cretaceous of Montana. Peabody Museum of Natural History, Bull Peabody Mus Nat Hist 30: 1-165.

Ostrom JH AND MCInTOSH JS. 1999. Marsh's dinosaurs: The Collections from Como Bluff. New Haven: Yale University Press, 388 p.

PAdian K, Hutchinson JR ANd Holtz JR TR. 1999. Phylogenetic definitions and nomenclature of the major taxonomic categories of the carnivorous Dinosauria (Theropoda). J Vert Paleontol 19: 69-80.

PARRISH JM. 1987. The origin of crocodilian locomotion. Paleobiology 13: 396-414. 
PAUL GS. 1988. Predatory dinosaurs of the world: A complete illustrated guide. New York: Simon and Schuster, $464 \mathrm{p}$.

PAUL GS. 1998. Limb design, function and running performance in ostrich-mimics and tyrannosaurs. Gaia 15: 257-270.

PAUL GS. 2002. Dinosaurs of the air: the evolution and loss of flight in dinosaurs and birds. Baltimore: The Johns Hopkins University Press, 472 p.

RAATH M. 1990. Morphological variation in small theropods and its meaning in systematics: evidence from Syntarsus rhodesiensis. In: CARPENTER K AND CURRIE PJ (Eds), Dinosaur systematics: Approaches and perspectives, Cambridge: Cambridge University Press, p. 91105.

RaYfield EJ, Norman DB, Horner CC, Horner JR, SMith PM, Thomason JJ AND UpChURCh P. 2001. Cranial design and function in a large theropod dinosaur. Nature 409: 1033-1037.

ROMER AS. 1922. The locomotor apparatus of certain primitive and mammal-like reptiles. Bull Am Mus Nat Hist 46: 517-606.

ROMER AS. 1923a. The pelvic musculature of saurischian dinosaurs. Bull Am Mus Nat Hist 48: 605-617.

Romer AS. 1923b. The ilium in dinosaurs and birds. Bull Am Mus Nat Hist 48: 141-145.

Romer AS. 1923c. Crocodilian pelvic muscles and their avian and reptilian homologues. Bull Am Mus Nat Hist 48: 533-552.

ROMER AS. 1942. The development of tetrapod limb musculature - the thigh of Lacerta. J Morphol 71: 251-298.

ROMER AS. 1956. Osteology of the reptiles. Chicago: University of Chicago Press, $772 \mathrm{p}$.

RowE T. 1986. Homology and evolution of the deep dorsal thigh musculature in birds and other reptilian. J Morphol 189: 327-346.

Rowe T And Gauthier J. 1990. Ceratosauria. In: WeIShAMPEL DB ET AL. (Eds), The Dinosauria, Berkeley: University of California Press, p. 151-168.

RUSSELl DA. 1972. Ostrich dinosaurs from the late Cretaceous of western Canada. Can J Earth Sci 9: 375-402.

Russell AP AND BELS V. 2001. Biomechanics and kinematics of limb-based locomotion in lizards: review, synthesis and prospectus. Comp Biochem Physiol A 131: 89-112.

SAMpson SD, Witmer LM, Forster CA, Krause DW, OCONNOR PM, DODSON P AND RAVOAVY F. 1998.
Predatory dinosaur remains from Madagascar: implications for the Cretaceous biogeography of Gondwana. Science 280: 1048-1051.

SCHWARZ D AND SAlisbury SW. 2005. A new species of Theriosuchus (Atoposauridae, Crocodylomorpha) from the Late Jurassic (Kimmeridgian) of Guimarota, Portugal. Geobios 38: 779-802.

SeEbacher F. 2001. A new method to calculate allometric length-mass relationships of dinosaurs. J Vert Paleontol 21: $51-60$.

SEN K. 2003. Pamelaria dolichotrachela, a new prolacertid reptile from the Middle Triassic of India. J Asian Earth Sci 21: 663-681.

SERENO PC. 1997. The origin and evolution of dinosaurs. Annu Rev Earth Planet Sci 25: 435-489.

SERENO PC. 1999. The evolution of dinosaurs. Science 284: 2137-2147.

Sereno PC AND ARCUCCI AB. 1993. Dinosaurian precursors from the Middle Triassic of Argentina: Lagerpeton chanarensis. J Vert Paleontol 13: 385-399.

SERENo PC AND ARCUCCI AB. 1994. Dinosaurian precursors from the Middle Triassic of Argentina: Marasuchus lilloensis gen. nov. J Vert Paleontol 14: 53-73.

SERENO PC AND Novas FE. 1992. The complete skull and skeleton of an early dinosaur. Science 258: 1137-1140.

StOKSTAD E. 2001. Did saurian predators fold up on turns? Science 293: 1572.

THULBORN RA. 1989. The gaits of dinosaurs. In: GILlETtE DD AND Lockley MG (Eds), Dinosaur Tracks and Traces, Cambridge: Cambridge University Press, p. 3950.

Troxell EL. 1925. Hyposaurus, a marine crocodilian. Am $\mathrm{J}$ Sci, $5^{\text {th }}$ Series 9: 489-514.

WADE M. 1989. The stance of dinosaurs and the Cossack Dancer Syndrome. In: Gillette DD AND LOCKLEY MG (Eds), Dinosaur Tracks and Traces, Cambridge: Cambridge University Press, p. 73-82.

WiLhite R. 2003. Digitizing large fossil skeletal elements for three-dimensional applications. Palaeontologia Electronica 5(2):10, 619KB; http://palaeo-electronica.org/2002_2/ scan/issue2_02.htm

WITMER LM. 1995. The extant phylogenetic bracket and the importance of reconstructing soft tissues in fossils. In: THOMASON JJ (Ed), Functional morphology in vertebrate paleontology, Cambridge: Cambridge University Press, p. 19-33. 
WiTMER LM. 1997. The evolution of the antorbital cavity of archosaurs: a study in soft-tissue reconstruction in the fossil record with an analysis of the function of pneumaticity. J Vert Paleontol 17: 1-73.

Xu X, Clark JM, Forster CA, Norell M, Erickson GM, EBERTh DA, JiA C AND ZHAO Q. 2006. A basal tyrannosauroid dinosaur from the Late Jurassic of China. Nature 439: 715-718.
YATES AM. 2003. A new species of the primitive dinosaur Thecodontosaurus (Saurischia: Sauropodomorpha) and its implications for the systematics of early dinosaurs. J Syst Palaeontol 1: 1-42.

ZaAf A, Herrel A, Aerts P And de Vree F. 1999. Morphology and morphometrics of the appendicular musculature in geckoes with different locomotor habits (Lepidosauria). Zoomorphology 119: 9-22. 